\title{
What happened in the South American Gran Chaco? Diversification of the endemic frog genus Lepidobatrachus Budgett, 1899 (Anura: Ceratophryidae)
}

\author{
Francisco Brusquetti $^{\mathrm{a}, *}$, Flavia Netto ${ }^{\mathrm{a}, \mathrm{b}}$, Diego Baldo ${ }^{\mathrm{c}}$, Célio F.B. Haddad ${ }^{\mathrm{d}}$ \\ a Instituto de Investigación Biológica del Paraguay, Del Escudo 1607, CP 1425 Asunción, Paraguay \\ b Itaipu Binacional, División de Áreas Protegidas, Dirección de Coordinación Ejecutiva, Av. Monseñor Rodriguez 150, Ciudad del Este, Alto Paraná, Paraguay \\ ${ }^{\mathrm{c}}$ Instituto de Biología Subtropical (IBS, CONICET-UNaM), Laboratorio de Genética Evolutiva, Facultad de Ciencias Exactas, Universidad Nacional de Misiones, Félix de \\ Azara 1552, CPA N3300LQF, Posadas, Misiones, Argentina \\ ' Departamento de Zoologia and Centro de Aquicultura, Instituto de Biociências, UNESP - Universidade Estadual Paulista, Rio Claro, Caixa Postal 199, 13506-900 Rio \\ Claro, SP, Brazil
}

\section{A R T I C L E I N F O}

\section{Keywords:}

Miocene marine introgression

Species tree

Fossil calibration

Lepidobatrachus asper

Lepidobatrachus laevis

Lepidobatrachus llanensis

\begin{abstract}
A B S T R A C T
The Chaco is one the most neglected and least studied regions of the world. This highly-seasonal semiarid biome is an extensive continuous plain without any geographic barrier, and in spite of its high species diversity, the events and processes responsible have never been assessed. Miocene marine introgressions and Pleistocene glaciations have been mentioned as putative drivers of diversification for some groups of vertebrates in adjacent biomes of southern South America. Here we used multilocus data (one mitochondrial and six nuclear loci) from the three species of the endemic frog genus Lepidobatrachus (Lepidobatrachus asper, Lepidobatrachus laevis, and Lepidobatrachus llanensis) to determine if any of the historical events suggested as drivers of vertebrate diversification in southern South America are related to the diversification of the genus and if the Chaco is indeed a biome without barriers. Using fossil calibration in a coalescent framework we estimated that the genus diversified in the second half of the Miocene, coinciding with marine introgressions. Genetic patterns and historical demography suggest an important role of old archs and cratons as refuges during floods. In one species of the genus, L. llanensis, genetic structure reveals some breaks along the landscape, the main one of which corresponds to an area of the central Chaco that may act as a climatic barrier. Additionally, we found differential effects of the main Chacoan rivers on species of Lepidobatrachus that could be related to the time of persistence of populations in the areas influenced by these rivers.
\end{abstract}

\section{Introduction}

It has become increasingly clear that the origin of extant Neotropical biodiversity is not restricted to a particular timeframe or mechanism (Rull, 2011). Diversification of extant biodiversity (fauna and flora) in the Neotropics is related to events and processes that have taken place from late Eocene/early Oligocene to Pleistocene (Rull, 2008). However, this understanding was based mainly on studies from tropical forests, such as the Amazon Forest and the Atlantic Forest, neglecting open biomes like those of the "diagonal of open formations" (sensu Vanzolini, 1963), including Caatinga, Cerrado, and Chaco. Collectively, these formations occupy about $4,600,000 \mathrm{~km}^{2}$ (Duellman, 1999) of strongly seasonal sub-humid to semiarid formations, which extend from central Argentina to northeastern Brazil, including large portions of Paraguay and Bolivia. However, it is clear that Caatinga, Cerrado, and Chaco are distinct biomes, each with its own identity
(Cabrera and Willink, 1973; Rizzini, 1979; Dinerstein et al., 1995; Olson et al., 2001). Among these biomes, the Chaco is the most neglected in terms of knowledge regarding its biodiversity evolutionary history (Werneck, 2011), because there is an absence of scientific studies addressing putative drivers of Chacoan species diversification, like dispersal barriers or historical events.

The Chaco is a semiarid biome with marked climatic seasonality (Prado, 1993; Cabrera, 1994), and is characterized by xerophytic vegetation formed by a mosaic of grassland, savannas, open woodlands, and xeric thorn forest (Willig et al., 2000). It spans from southeastern Bolivia to central Argentina, occupying more than $60 \%$ of Paraguay and a small portion of midwestern Brazil, in the state of Mato Grosso do Sul. The Chaco is one of the most extensive continuous forested areas in South America with an approximate extent of $1,000,000 \mathrm{~km}^{2}$ (Bucher, 1982). The Chaco is an extensive sedimentary alluvial plain with soils derived from the accumulation of fine loess and alluvial sediments

\footnotetext{
* Corresponding author.

E-mail address: franbrusquetti@gmail.com (F. Brusquetti).
} 
during the Quaternary (Pennington et al., 2000). This biome has historically been considered a continuum, without geographical barriers to organismal dispersion (Bucher, 1982). However, some potential barriers occur throughout the Chaco. Close to its southern and western limits, some elevated areas are present, such as some of the mountains of the Sierras Pampeanas in northern Córdoba, Argentina, and the Sierras Subandinas in Catamarca and La Rioja, also Argentinean provinces. Furthermore, some rivers cross the Chaco in a west-east direction until their confluence with the Paraguay and Paraná rivers. The main Chacoan rivers are the Pilcomayo, Bermejo, Salado, and Dulce. These rivers are allochthonous, having their headwaters in the Andes, and possess flowing water only during the rainy season, with their channels losing water by infiltration during the rest of the year (Iriondo, 1993). Furthermore, these rivers carry large amounts of sediment that eventually fill channels and cause the rivers to change their courses, thereby forming large alluvial fan systems. The Chaco, as currently known, is the result of the Andean uplift (Gregory-Wodzicki, 2000), marine introgressions (Hernández et al., 2005), and several alluvial fan systems (Iriondo, 1993), which have continuously influenced the distribution and the climatic conditions of this biome, since the Paleogene until today. Other geographically important historical events in southern South America are glaciations, many of which contributed to climatic changes in these latitudes (Ortiz-Jaureguizar and Cladera, 2006).

Miocene marine introgressions have been suggested as probable drivers of diversification of some vertebrate groups in southern South America, like some mammals and reptiles (Candela et al., 2012; Delsuc et al., 2012; Morando et al., 2014). At least three extensive marine introgressions have been recorded for this region (Ottone et al., 2013). The most important in extension, the Paranense Sea, occurred between 15 and 13 million years ago (Ma), and covered almost the entire current distribution of the Chaco (Hernández et al., 2005; Candela et al., 2012; Ottone et al., 2013). Like marine introgressions, Pleistocene glaciations with associated refugia have also been proposed as diversification mechanisms for southern South America (Nuñez et al., 2011; Blotto et al., 2013; Langone et al., 2016). The main South American Pleistocene glaciations occurred during the last million years (Rabassa and Clapperton, 1990; Ruzzante et al., 2008).

The frog genus Lepidobatrachus is an interesting model for testing hypotheses about drivers of diversification in the Chaco biome. This monophyletic taxon contains three species (Lepidobatrachus asper, Lepidobatrachus laevis, and Lepidobatrachus llanensis) with geographical distributions restricted to the Gran Chaco (Faivovich et al., 2014). These species are mostly aquatic, inhabit temporary ponds, and exhibit several characteristics associated with survival in semiarid environments, such as cocoon formation and short duration of larval development (Faivovich et al., 2014). When ponds dry, these frogs burrow into the humid soil and produce a cocoon of dead skin, which helps to protect against desiccation during the dry period of estivation (Faivovich et al., 2014). In a similar manner, their short larval development is also related to the ephemeral nature of their aquatic habitats by helping to minimize or to prevent larval desiccation. This set of characteristics, which are closely related to the ephemeral water regime of their preferred habitats, would lead us to think that species of Lepidobatrachus experience strong barriers to dispersal and consequently a decreased gene flow and high levels of population differentiation, which further contributes to making this genus a great candidate to study patterns of diversification in the Chaco.

The two main events that have been proposed as drivers of diversification of vertebrates of southern South America occurred during two different and widely separated time periods; middle-Miocene marine introgressions between 15 and $13 \mathrm{Ma}$ and Pleistocene glaciations in the last $1 \mathrm{Ma}$. With the delimitation of a temporal framework we can infer the most plausible diversification driver within Lepidobatrachus and study the mechanisms involved in this process. Both marine introgressions and glaciations have been suggested as drivers of diversification of some groups of species by isolating populations in suitable areas and promoting opportunities for speciation by geographical isolation. If indeed marine introgressions isolated populations of Lepidobatrachus in areas protected from flooding, we should be able to find genetic signatures of these events. These signatures should help in the identification of stable areas where populations have persisted for longer periods of time, as well as the direction of subsequent expansions, when habitats became suitable again. The same type of pattern is expected for refugia during glaciations, for which we expect higher genetic diversity at stable areas and genetic signatures of expansion in unstable or recently colonized areas (Hewitt, 1996).

Here we used a multilocus dataset with samples of the three species of Lepidobatrachus from throughout the entire distribution of the genus to address two main questions: (1) are any of the historical events suggested as drivers of diversification of vertebrates of southern South America (marine introgressions and glaciations) also related to Lepidobatrachus diversification; and (2) is the Chaco indeed a barrierfree biome as has been suggested? To answer these questions we: estimated the diversification time frame for the genus to correlate it with historical events; estimated genetic diversity indices and tested for demographic expansions in order to identify areas where each lineage may have been isolated; and investigate the genetic structure and genetic differentiation among populations, with the specific objective of identifying putative dispersal barriers across the Chaco.

\section{Material and methods}

\subsection{Sampling}

We included 24 samples from six localities of L. asper, 79 samples from 26 localities of $L$. laevis, and 89 samples from 27 localities of $L$. llanensis (Fig. 1; Appendix A). Voucher specimens are housed in the Herpetological Collection of the Instituto de Investigación Biológica del Paraguay (IIBP-H), Asunción, Paraguay; Laboratorio de Genética Evolutiva (LGE, JNL, and LL), Posadas, Argentina; Museo Argentino de Ciencias Naturales (MACN and BB), Buenos Aires, Argentina; and in the Coleção Zoológica de Referência da Universidade Federal do Mato Grosso do Sul (ZUFMS), Corumbá, Brazil.

\subsection{Laboratory procedures and molecular methods}

We extracted total genomic DNA from samples preserved in 95-100\% ethanol (muscle or liver), using the DNeasy extraction kit (Qiagen, Valencia, CA, USA) following the manufacturer's protocol. We amplified one mitochondrial fragment and six nuclear introns via polymerase chain reaction (PCR) using published primers (Table 1) and a commercial kit (Master Mix, Fermentas). In cases where a locus was not previously referred with an abbreviation, we used the pair of primers to name it throughout the text. For the amplification of the mitochondrial gene we used a step-up reaction (UP) following Lyra et al. (2016). The UP reaction consisted of an initial denaturation step with $3 \mathrm{~min}$ at $95^{\circ} \mathrm{C}, 10$ cycles of denaturation for $20 \mathrm{~s}$ at $95^{\circ} \mathrm{C}$, annealing for $20 \mathrm{~s}$ at $50^{\circ} \mathrm{C}$ (increasing $+0.5^{\circ} \mathrm{C}$ in each subsequent cycle) and extension for $50 \mathrm{~s}$ at $60^{\circ} \mathrm{C}$; followed by 25 cycles of denaturation for $15 \mathrm{~s}$ at $95^{\circ} \mathrm{C}$, annealing for $20 \mathrm{~s}$ at $50{ }^{\circ} \mathrm{C}$, extension for $50 \mathrm{~s}$ at $60^{\circ} \mathrm{C}$, and final extension for $5 \mathrm{~min}$ at $60^{\circ} \mathrm{C}$. For the amplification of the nuclear genes we used an initial denaturation step of $3 \mathrm{~min}$ at $94^{\circ} \mathrm{C}$, followed by 35 cycles (45 cycles for difficult samples) (30 s of denaturation at $95^{\circ} \mathrm{C}$, $30 \mathrm{~s}$ of annealing at $50-64.3^{\circ} \mathrm{C}$, and $45 \mathrm{~s}$ of extension at $72^{\circ} \mathrm{C}$ ), and a final extension step of $7 \mathrm{~min}$ at $72^{\circ} \mathrm{C}$ (see Table 1 for details). We purified PCR products using ExoSAP (Fermentas) and sent them to Macrogen Inc. (Seoul, South Korea) for sequencing. We checked chromatograms and edited sequences in CodonCode Aligner v. 3.5.4 (Codon Code Corporation). GenBank Accession Numbers are listed in Appendix $\mathrm{B}$, sequences with less than 200 base pairs are deposited in the Dryad Repository (https://doi.org/10.5061/dryad.mn183qg). In the 


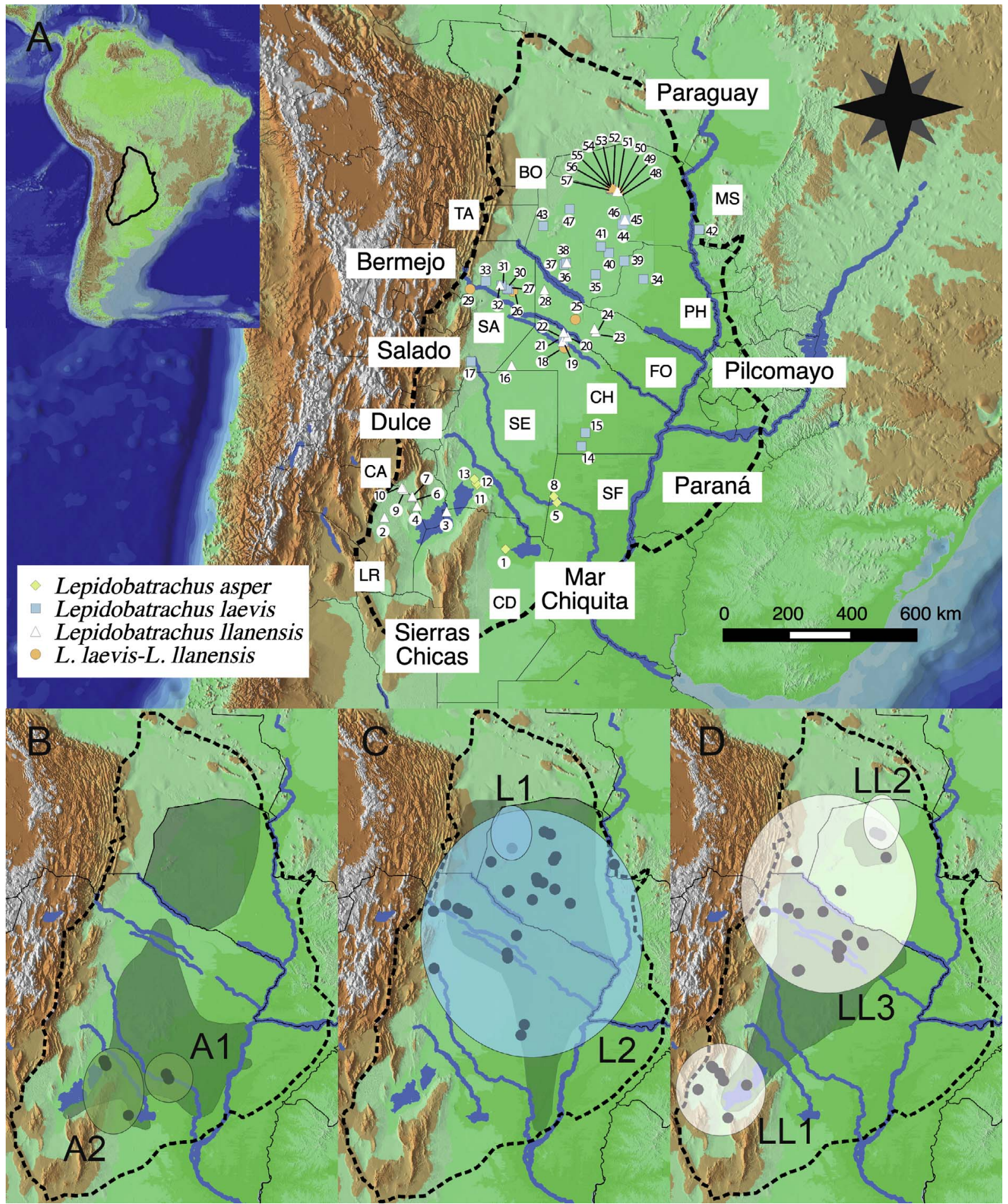

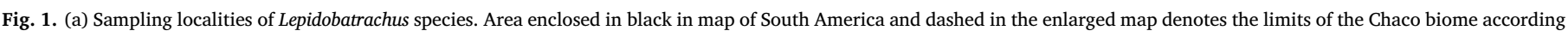

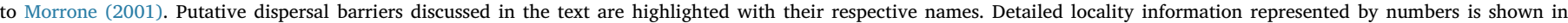

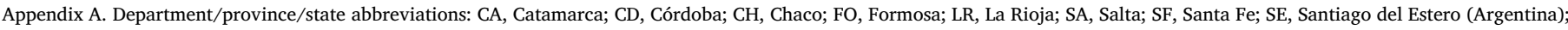

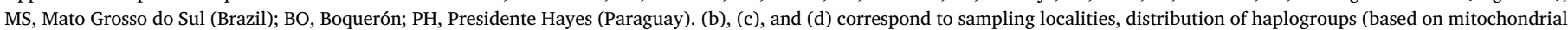

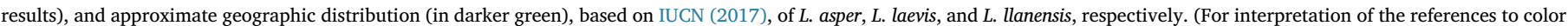
in this figure legend, the reader is referred to the web version of this article.)

subsequent analyses we used one to five samples per locality for the mitochondrial gene and one or two samples per locality for the nuclear genes (Fig. 1; Appendix B).

We aligned sequences from each fragment separately with MUSCLE (Edgar, 2004) in MEGA 6 (Tamura et al., 2013) and checked by eye. We separated sequences of individuals with heterozygous indels with the algorithm Process Heterozygous Indels in CodonCode Aligner v. 3.5.4 and used Phase 2.1 (Stephens et al., 2001) implemented in DnaSP 5.1 (Librado and Rozas, 2009) to resolve haplotypes of heterozygous individuals, discarding those resolved with less than 0.90 posterior probability. We generated haplotypes in DnaSP. Within nuclear loci, we tested for recombination with PhiTest implemented in Splitstree v4.2 
Table 1

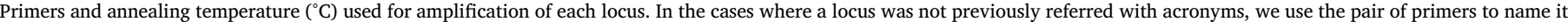
throughout the text.

\begin{tabular}{|c|c|c|c|}
\hline Locus ID (base pair number) & Primer sequence $5^{\prime}-3^{\prime}$ & Annealing & Reference \\
\hline CO1 (600 bp) & ANF1 ACHAAYCAYAAAGAYATYGG & $45 / 50$ & Jungfer et al. (2013) \\
\hline Cytochrome $c$ oxidase subunit 1 & ANR1 CCGGTCTGAACTCAGATCACGT & & Jungfer et al. (2013) \\
\hline GAPDH (297 bp) & MVZ15 ACACCСACTCСTCTATCTTTGATG & 54.7 & Bell et al. (2011) \\
\hline Glyceraldehyde-3 Phosphate Dehydrogenase (intron 4) & MVZ16 AAATGTAAGCTAAGAGATCCACAAC & & Bell et al. (2011) \\
\hline MVZ 27-28 (352 bp) & MVZ27 ATTATTCCGTAACAGCAAACTC & 54.7 & Bell et al. (2011) \\
\hline Lactose Dehydrogenase Chain Beta (Intron 3) & MVZ28 GTAACCATGGCAACTGGTAG & & Bell et al. (2011) \\
\hline MVZ 29-30 (198 bp) & MVZ29 ATCCTCCATACTACTTAAGGAGACC & 57 & Bell et al. (2011) \\
\hline Y Box Binding (Intron 1) & MVZ30 CTGAAGCCTCTGTACATGTTTTG & & Bell et al. (2011) \\
\hline MVZ 39-40 (180 bp) & MVZ39 GGATCTGCTAGAGACCTGTCACTTC & 57 & Bell et al. (2011) \\
\hline X. laevis MGC82783 protein (Intron 2) & MVZ40 ACAGAGTCTTCAAACCCAGCAATAC & & Bell et al. (2011) \\
\hline MVZ 47-48 (340 bp) & MVZ47 AGTGAAAGATACAGTCACAGTGCTAGG & $54.7 / 56.7 / 59$ & Bell et al. (2011) \\
\hline Fibrinogen, A alpha polypeptide (Intron 1) & MVZ48 GGAGGATATCAGCACAGTCTAAAAAG & & Bell et al. (2011) \\
\hline RPL3 (413 bp) & RPL35F AAGAAGTCYCACCTCATGGAGAT & $50 / 53 / 64.3$ & Pinho et al. (2009) \\
\hline Ribosomal Protein L3 (Intron 5) & RPL36RA AGTTTCTTTGTGTGCCAACGGCTAG & & Pinho et al. (2009) \\
\hline
\end{tabular}

(Huson and Bryant, 2006).

\subsection{Species-tree and diversification-time estimation}

To infer the species tree and to estimate a timeframe of diversification for the genus Lepidobatrachus, we used the multilocus coalescent model implemented in "Beast (Heled and Drummond, 2010) on Beast 2.4.3 (Bouckaert et al., 2014), considering the seven loci (CO1 and the six nuclear introns) and available sequences for Lepidobatrachus species in GenBank for the genes $12 S$ (926 bp), $16 S$ (1428 bp), cytochrome $b$ (CytB) (1003 bp), NADH dehydrogenase subunit 1 (ND1) (961 bp), exon 2 of chemokine receptor 4 (CXCR4) (676 bp), proopiomelanocortin A gene $(P O M C)$ (556 bp), recombination-activating gene 1 (RAG1) (428 bp), exon 1 of rhodopsin (RHOD) (316 bp), seven in absentia homolog 1 (SIAH) (397 bp), and tyrosinase (TYR) (532 bp), for a total of five mitochondrial and 12 nuclear fragments, and $9603 \mathrm{bp}$. For this analysis, we included only samples with sequences for at least four loci including $\mathrm{CO} 1$ sequence to diminish missing data and to ensure some amount of common sequence (see Appendix B). We included a total of 11 individuals of $L$. asper, 38 individuals of $L$. laevis, 29 individuals of $L$. llanensis, and two individuals of each species used as outgroup. Sequences were not combined across loci and individuals. Nucleotide substitution model, range of the rate of heterogeneity, and proportion of invariant positions were inferred during the MCMC analysis with bModelTest package (Bouckaert, 2015) implemented in Beast, with transition-transversion split option and empirical frequencies.

To assess clock models that best fit our dataset we ran exploratory analyses of each locus in standard Beast with uncorrelated lognormal relaxed clock using Coefficient of Variation (CV) as indicator of goodness of fit. CV is indicative of how much variation among rates is implied by the data; values below 0.1 are considered strong evidence for the use of the strict clock (Drummond and Bouckaert, 2015). The Strict Clock model was used only for the nuclear loci MVZ 27-28, MVZ 29-30, MVZ 39-40, and RPL3; the Relaxed Clock Log Normal model was used for all the other loci.

Fossil calibration is largely the best practice to estimate divergence time; however, justifying the use of a fossil record is not trivial (Parham et al., 2012). Several authors have recently questioned the taxonomic position of the fossils historically assigned to Ceratophryidae, Beelzebufo ampinga (Evans et al., 2008), Baurubatrachus pricei (Báez and Perí, 1989), and Wawelia geroldhi (Casamiquela, 1963) (Agnolín, 2012; Báez et al., 2005; Faivovich et al., 2014; Nicoli et al., 2016), and their use as calibration points (Faivovich et al., 2014; Nicoli et al., 2017). On the other hand, in the last few years fossil data for Ceratophryidae significantly increased, with several new fossil records for the genus Ceratophrys and one for the genus Lepidobatrachus (Fernicola, 2001; Tomassini et al., 2011; Nicoli, 2014; Nicoli et al., 2017). The only record of Lepidobatrachus corresponds to the fossil species Lepidobatrachus australis (Nicoli, 2015), which is from the late Miocene-early Pliocene from Farola Monte Hermoso, Buenos Aires, Argentina (Tomassini et al., 2011, 2013; Fernicola, 2001; Nicoli, 2015), dated between 5 and 6.8 Ma (Cione et al., 2007). In "Beast analysis we used a log-normal distribution with $M=1.0, S=1.25$, offset $=5$ based on the minimum possible age of the $L$. australis fossil in order to constrain the minimum bound for the node of the clade that includes all species of the genus Lepidobatrachus. The maximum bound, although it is a soft limit, is based on the combination of the Ceratophrys-Lepidobatrachus divergence suggested by Roelants et al. (2007), Heinicke et al. (2009), and Ruane et al. (2011) (without B. ampinga as a calibration point) and on the Ceratophrys-Chacophrys + Lepidobatrachus divergence suggested by Frazão et al. (2015). With these parameters the 5-95\% prior distribution lies between 5.23 and 26.2 Ma.

Among the markers used, a mutation rate is available for only CO1. Freilich et al. (2014) estimated that the CO1 mutation rate is about $25 \%$ slower than the ND2 mutation rate, and corresponds to $0.78 \%$ per lineage per million years. Meng et al. (2014), based on general mitochondrial rates, proposed $0.65 \%$ per lineage per million years. Based on both available rates we used $0.7 \%$ per lineage per million years as the mean in a normal distribution (sigma $=0.0005$ ) under an uncorrelated lognormal relaxed clock model in order to cover both estimations (5-95\% prior distribution between 0.618 and $0.782 \%$ ). We ran 400 million generations sampling every 40,000 with Yule model tree prior and constant population size. All mitochondrial genes were set up to use the same tree model. We used the software Tracer 1.5 (Rambaut et al., 2013) to check stationarity of the Markov chains by examining the effective sample size (ESS) values (ESS $>200$ was expected at stationarity). Analyses were repeated three times to assess consistency among results. The species tree was inferred with TREEANNOTATOR as a maximum clade credibility tree and median heights as node ages; the first 1000 trees were discarded as burn-in.

\subsection{Population structure: network haplotype genealogies and Bayesian population assignment analyses}

We generated haplotype genealogies for each locus using Haploviewer (Salzburger et al., 2011). Haploviewer turns phylogenetic trees into haplotype networks. We used DNAML available in PHYLIP v.3.695 package (Felsenstein, 2005) to generate a maximum-likelihood tree. To visualize the genetic structure within species and the influence of the main rivers on genetic structure we generated each genealogy two times, identifying haplotypes (1) by species and (2) by populations separated by rivers.

To assess the genetic assignment of individuals to genetic clusters we used a model-based clustering method implemented in STRUCTURE 
2.3.4 (Pritchard et al., 2000). Using multilocus genotypic data, STRUCTURE divides individuals into a number of genetic clusters (K) (irrespectively of locality information), to minimize deviations from HardyWeinberg and linkage equilibrium within each cluster, and also calculates the fractional membership of each individual to each cluster (Q). For STRUCTURE analysis, we included only nuclear loci and only samples with sequences for at least four loci (see Appendix B). We used the program xmfa2struct (available at: http://www.xavierdidelot. xtreemhost.com/clonalframe.htm) to convert sequences to STRUCTURE input; this program encodes each variable site as an allele. We performed ten independent runs for each $\mathrm{K}$ with admixture model and independent allele frequencies inferring lambda. For each $\mathrm{K}$ ranging from 1 to 15 , we performed $5 \times 10^{5}$ iterations as burn-in and $5 \times 10^{5}$ additional iterations. The most likely $\mathrm{K}$ was based on the highest mean value of the likelihood distribution via the on-line program STRUCTURE HARVESTER v.0.6.93 (Earl, 2012). We assembled the multiple runs for each K in CLUMPP v.1.1.2 (Jakobsson and Rosenberg, 2007) and visualized with DISTRUCT v.1.1 (Rosenberg, 2004).

\subsection{Genetic diversity, genetic differentiation between populations and neutrality tests}

For each mitochondrial haplogroup we estimated haplotype diversity ( $H d$ : the probability that two randomly chosen haplotypes are different; Nei, 1987) and per-site nucleotide diversity (Pi: the average number of nucleotide differences per site between two randomly chosen DNA sequences; Nei, 1987) in DnaSP software. We estimated Fst in DnaSP and net mean distances [Da in DnaSP (Tamura and Nei, 1993)] between mitochondrial haplogroups within species in order to identify genetic breaks. Significance of Fst and $D a$ was assessed with the Permutation Test by 5000 replications. To detect significant deviations from the null hypothesis of neutral evolution and constant population size we performed Tajima's $D$ (Tajima, 1989), Fu's Fs (Fu, 1997) and Ramos-Onsins and Rozas's $R 2$ tests (Ramos-Onsins and Rozas, 2002). Significance levels of $F s, R 2$, and $r$ were estimated with 10,000 coalescent simulation replicates. Statistics and significance analyses were made in DnaSP.

\subsection{Demographic history}

We used the multilocus coalescent-based extended Bayesian Skyline plot (EBSP; Heled and Drummond, 2008) implemented in Beast 2.4.3 to estimate changes in effective population size through time. We analyzed each mitochondrial haplogroup separately using all loci, mitochondrial and nuclear (LL2 was not analyzed due to low number of sequences in nuclear loci). For each analyzed group we used the CO1 substitution rate as reference, with 0.007 substitution/site/year based on Freilich et al. (2014) and Meng et al. (2014) estimations, with a strict molecular clock and uniform priors [except for RPL3 marker of LL3, which was gamma distributed (Alpha 0.0010, Beta 1000, Offset 0.0)]. Nucleotide substitution model, range of the rate of heterogeneity, and proportion of invariant positions were inferred during the MCMC analysis with bModelTest package implemented in Beast with transition-transversion split option and empirical frequencies. We ran 400 million Markov chain Monte Carlo simulations sampled every 40,000 chains. Chain convergence was assessed in Tracer 1.5 by effective sample size (ESS) examination ( $>200$ ).

\subsection{Isolation-with-migration model}

We estimated time of divergence, gene flow after split with its direction, and population size of ancestral and current populations between populations of L. llanensis from north and south of the Santiago del Estero gap with an isolation-with-migration model (Hey and Nielsen, 2007) implemented in IMa2 (Hey, 2010). Analyses were made using LL1 and LL3 as sampling populations because of their closer relationship (see Fig. 3a). Following the authors of IMa2, we first tested the HKY model (Hasegawa et al., 1985) for mitochondrial data and the IS model (Kimura, 1969) for nuclear data. However, HKY was used for all loci because IS was not compatible with our nuclear data. We used $0.7 \%$ per lineage per million years as the $\mathrm{CO} 1$ mutation rate based on Freilich et al. (2014) and Meng et al. (2014), transformed to a mutation rate per locus per year. Upper bounds for population size, migration, and divergence time $(-q,-m$, and $-t$, respectively) were based on the population mutation rate (theta) estimated in DnaSP following the authors' recommendations. After pilot-run adjustment we used uniform distribution for population-size and divergence-time priors with upper bounds set as $-q 18.95-m 0.53-t 7.58$. We ran in M mode (MCMC) three times with different seed numbers with 20 Markov chains with the following heating terms: -hfg -hn40 -ha0.975 -hb0.75. Each simulation corresponds to $10 \times 10^{5}$ of burn-in and 20,000 saved genealogies. We assumed a generation time of one year based on the rapid larval development (including metamorphosis) and fast postmetamorphic growth of Lepidobatrachus species (Fabrezi and Quinzio, 2008; also see Faivovich et al., 2014). MCMC mixing was assessed through Effective Sample Sizes (ESSs) and trend-line plots; both denote levels of autocorrelation among samples and swapping rates between chains over the run.

\section{Results}

\subsection{Species-tree}

Since our main goal with the species-tree analysis was to delimit a timeframe of diversification within Lepidobatrachus, we assigned samples to the three species of the genus. All runs resulted in the same tree and effective samples sizes (ESS) were $>200$ for all parameters denoting a high confidence of the estimates. The analysis recovered $L$. asper as the sister taxon of L. laevis + L. llanensis. According to our data, the first and second split were relatively close and with a high level of overlap [8.73-16.82 and 6.48-13.26 Ma of 95\% highest posterior density (HPD) interval, respectively], corresponding to the second half of the Miocene (Fig. 2).

\subsection{Population structure: network haplotype genealogies and Bayesian population assignment analyses}

The COI haplotype network (Fig. 3a) showed three main haplogroups separated by $\sim 60$ mutations, which correspond to each Lepidobatrachus species. The four haplotypes of $L$. asper were grouped in pairs separated by nine mutations. One pair corresponds to all haplotypes from Santa Fe (A1) and the other corresponds to haplotypes from Córdoba and Santiago del Estero (A2) (Fig. 1b). In L. laevis, one haplotype shared by the only two individuals from Teniente Prieto (Boquerón) (L1) (Fig. 1c) was separated by seven mutations from all other haplotypes (L2). In this major haplogroup (L2), four most frequent haplotypes were evident, each one surrounded by several rare haplotypes. Within L. llanensis, three haplogroups were evident. The first one, with few and common haplotypes, corresponded to individuals from Córdoba, La Rioja, and Catamarca provinces, in the southern distribution of the species (LL1) (Fig. 1d). Populations from the northern distribution of the species were clustered in two main haplogroups, one corresponding to a highly frequent haplotype shared by a large number of individuals, and two more of only one individual each. All individuals that share this haplogroup are from Defensores del Chaco (Boquerón, Paraguay) (LL2) (Fig. 1d), which was separated from all other L. llanensis by 11 (LL1) and 10 (LL3) mutation steps. The other haplogroup (LL3) shows a high number of rare haplotypes connected to each other by one to three mutations.

The only nuclear marker (Appendix C) that does not clearly separate the three Lepidobatrachus species, is GADPH. In this genealogy, L. asper shows three haplotypes; one shared by Córdoba and Santiago del Estero 


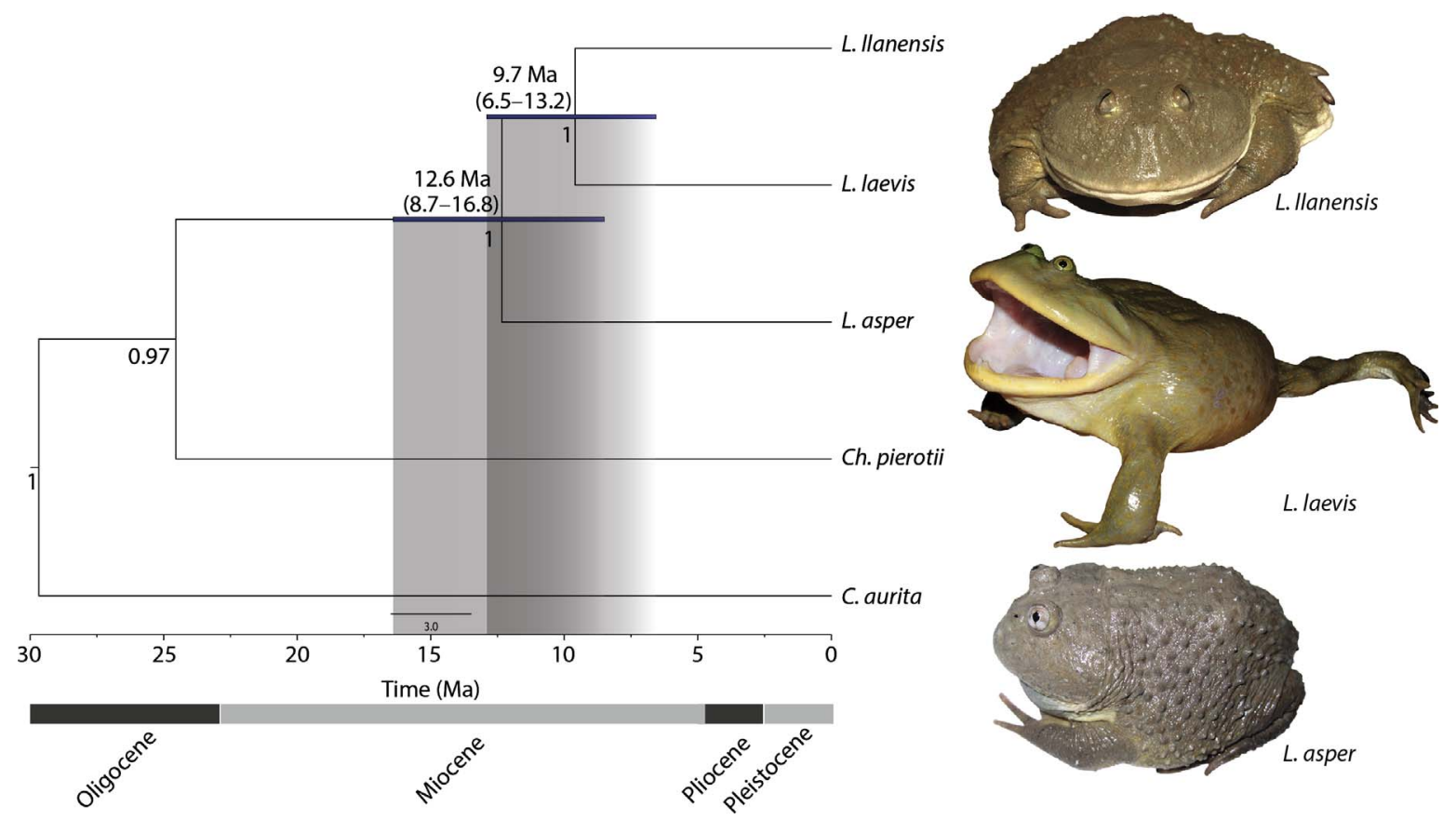

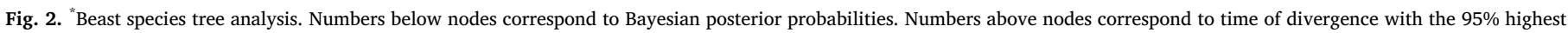
posterior density intervals (HPD) in parenthesis and also represented by bars. Divergence times expressed in million years. Ch. corresponds to Chacophrys and C. to Ceratophrys.

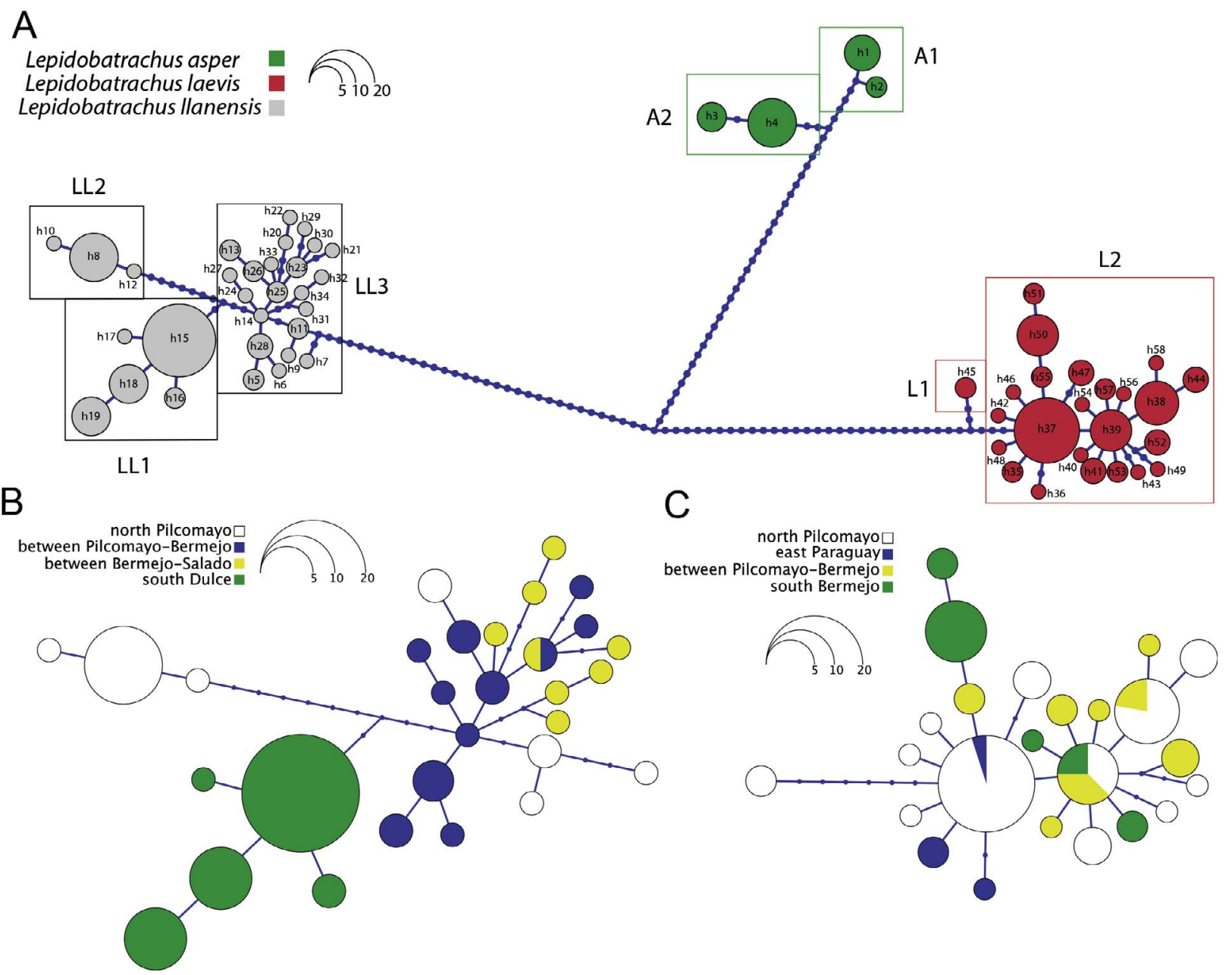

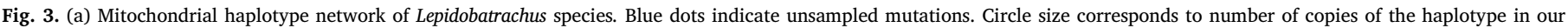

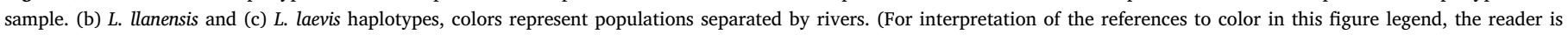
referred to the web version of this article.) 
individuals and the other two shared by Santa Fe individuals. The Córdoba + Santiago del Estero haplotype was closer to L. laevis haplotypes, and the Santa Fe haplotypes to L. llanensis haplotypes. In MVZ 27-28 and RPL3, L. asper haplotypes were shared by individuals from Córdoba and Santa Fe, but in MVZ 27-28 an individual from Córdoba shared a haplotype with Santiago del Estero individuals as well. In MVZ 29-30, MVZ 39-40, and MVZ 47-48, each locality exhibited exclusive haplotypes.

The most common pattern in L. laevis is many rare haplotypes without any geographic pattern (GADPH, MVZ 29-30, MVZ 39-40). In MVZ 47-48, the most frequent haplotype is surrounded by some rare haplotypes; however, the rest of the haplotypes do not show any pattern. In MVZ 27-28, the two most frequent haplotypes, and in RPL3, the one most frequent haplotype, were surrounded by many rare haplotypes (Appendix C).

In L. llanensis, GADPH and RPL3 exhibit a predominance of rare haplotypes without any geographic pattern. In MVZ 39-40 the most frequent haplotype is surrounded by some rare haplotypes, but the others did not show any pattern. In MVZ 29-30, the four most frequent haplotypes exhibit few associated rare haplotypes. The pattern for MVZ 27-28 and MVZ 47-48 is that of only one most frequent haplotype surrounded by some rare haplotypes (Appendix C).

For L. llanensis, the CO1 genealogy shows exclusive haplotypes for all between-rivers comparisons, except for one haplotype shared by two individuals separated by the Bermejo River (Fig. 3b). Populations south of the Dulce River were clearly separated; however, a long geographic distance (about $400 \mathrm{~km}$ ) and the Santiago del Estero gap are between these populations and the remaining populations of L. llanensis. Haplotypes north of the Pilcomayo River constitute two haplogroups. One of these haplogroups, which contains haplotypes from almost all the localities, was separated by several mutational steps. The remaining haplotypes from north of the Pilcomayo, and those from both sides of Bermejo River, exhibited mixed relationships. For L. laevis, the CO1 genealogy shows high levels of admixture between populations separated by rivers, and shared haplotypes between individuals from both sides of all rivers (Fig. 3c).

In STRUCTURE analyses, the mean likelihood reached a plateau at
Table 2

Genetic diversity of Lepidobatrachus main mitochondrial haplogroups. Higher genetic diversity is expected for populations with longer persistence time on the referred area.

\begin{tabular}{lllll}
\hline haplogroups & $N$ & $H$ & $H d$ & $P i$ \\
\hline Lepidobatrachus asper A1 & 8 & 2 & 0.429 & 0.00143 \\
Lepidobatrachus asper A2 & 15 & 2 & 0.419 & 0.00140 \\
Lepidobatrachus laevis L2 & 77 & 23 & 0.898 & 0.00384 \\
Lepidobatrachus llanensis LL1 & 42 & 5 & 0.602 & 0.00147 \\
Lepidobatrachus llanensis LL2 & 12 & 3 & 0.318 & 0.00056 \\
Lepidobatrachus llanensis LL3 & 31 & 23 & 0.981 & 0.00780
\end{tabular}

Note: Columns correspond to: number of individuals $(N)$, number of haplotypes $(H)$, haplotype diversity ( $\mathrm{Hd}$ : the probability that two randomly chosen haplotypes are different), and nucleotide diversity ( $P i$ : the average number of nucleotide differences per site between two randomly chosen DNA sequences). Haplogroup names follow Fig. 3. Lepidobatrachus laevis L1 not included because it corresponds to a unique haplotype in the mitochondrial genealogy.

$\mathrm{K}=3$, continuing with little variation up to $\mathrm{K}=15$ (Fig. 4a). In $\mathrm{K}=3$ each deme corresponds to one Lepidobatrachus species. Starting from $\mathrm{K}=4$ an ephemeral admixture in some individuals is evident but keeping the same main structure that of $\mathrm{K}=3$.

\subsection{Genetic diversity, genetic differentiation between mitochondrial haplogroups, and neutrality tests}

Haplotype diversity $(\mathrm{Hd})$ and nucleotide diversity $(\mathrm{Pi})$ were relatively low in both $L$. asper haplogoups (A1 and A2). In L. laevis (only for L2 because haplogroup L1 had only two individuals) $H d$ is very high and $P i$ relatively low. In L. llanensis, the southern haplogroup (LL1) shows medium to high $H d$ values and very low $P i$. Both genetic diversity indices ( $\mathrm{Hd}$ and $\mathrm{Pi}$ ) were very low for LL2 and very high for LL3 (Table 2). We found relatively high genetic differentiation and low genetic distance among all haplogroups within the species (Fst range from 0.63 to 0.94 and $D a$ range from 0.007 to 0.017 ; Table 3).

According to neutrality tests, there is no statistical support to accept a recent history of population expansions for both $L$. asper haplogroups (A1 and A2) and the L. llanensis haplogroup from the southern part of
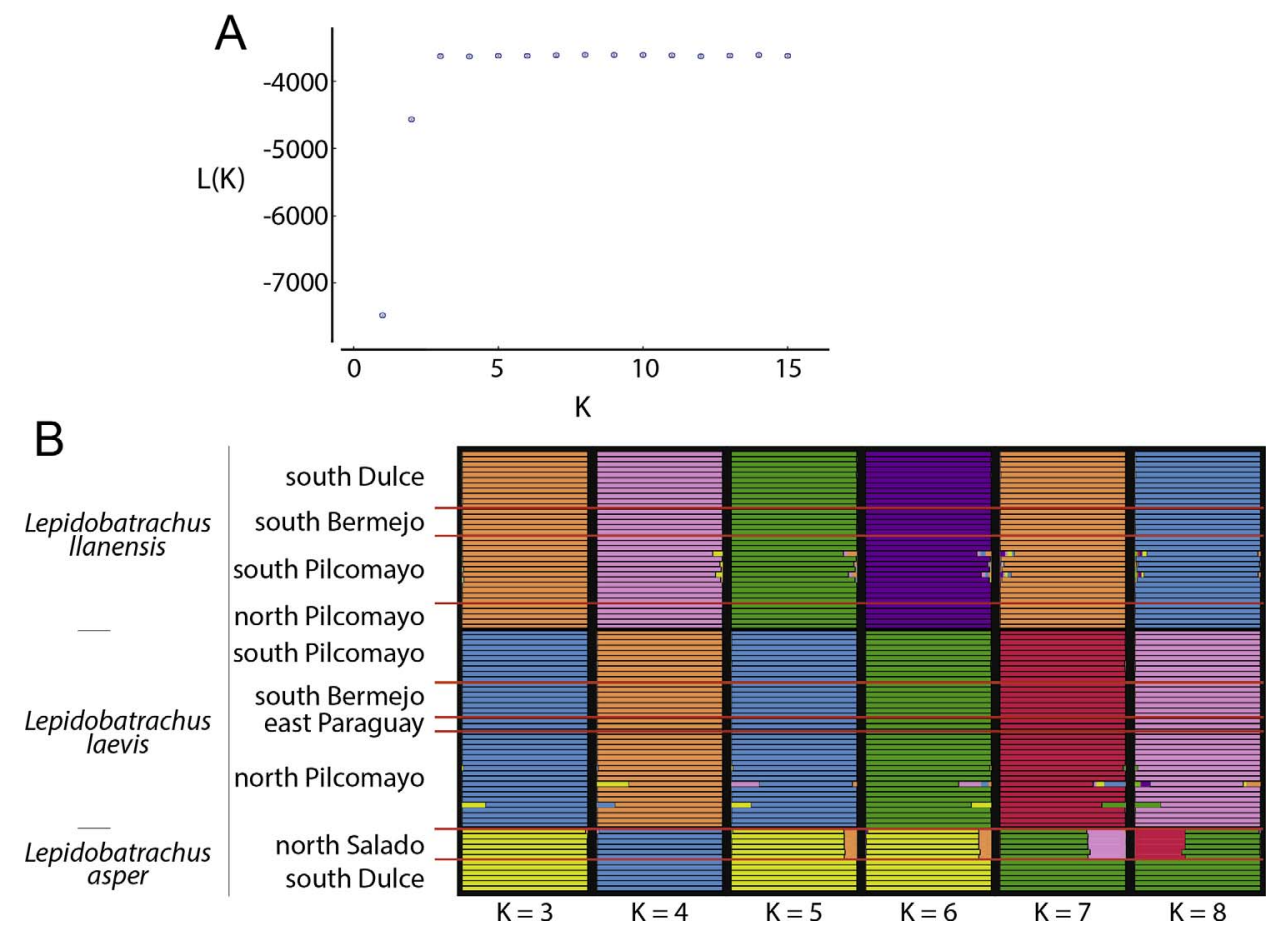

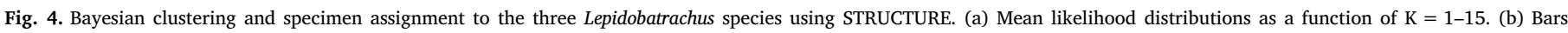
correspond to each specimen and their membership coefficient (q). Clusters are represented by color. Sampling sites are plotted by species (Appendix A). 
Table 3

Pairwise Fst and $D a$ values for mitochondrial fragment (CO1) among haplogroups within Lepidobatrachus species (see Fig. 3). Fst is inversely proportional to gene flow; lower values denote high levels of gene flow. $D a$ is a genetic distance calculation based on nucleotide substitutions per site between populations.

\begin{tabular}{lll}
\hline & Fst & Da \\
\hline Lepidobatrachus asper A1-A2 & 0.911 & 0.014 \\
Lepidobatrachus laevis L1"-L2 & 0.862 & 0.012 \\
Lepidobatrachus llanensis LL1-LL2 & 0.947 & 0.017 \\
Lepidobatrachus llanensis LL2-LL3 & 0.828 & 0.017 \\
Lepidobatrachus llanensis LL1-LL3 & 0.664 & 0.008 \\
\hline
\end{tabular}

Note: A1 ( $=8)$, A2 $(n=15)$, L1 $(n=2)$, L2 $(n=77)$, LL1 $(n=42)$, LL2 $(n=12)$, LL3 $(\mathrm{n}=31)$. $\mathrm{L} 1$ * corresponds to a unique haplotype in the mitochondrial genealogy.

Table 4

Neutrality tests (Tajima's D, Fu's Fs, R2 test) within Lepidobatrachus haplogroups. Significant values (highlighted in bold) denote deviations from the null hypothesis of neutral evolution, whose rejection suggest an increase in population size.

\begin{tabular}{llll}
\hline haplogroups & $D$ & $F s$ & $R 2$ \\
\hline Lepidobatrachus asper A1 & 0.41421 & 1.653 & 0.2143 \\
Lepidobatrachus asper A2 & 0.95399 & 2.222 & 0.2095 \\
Lepidobatrachus laevis L2 & $-\mathbf{1 . 8 0 1 8 4}$ & $-\mathbf{1 4 . 4 3 8}$ & $\mathbf{0 . 0 4 0 4}$ \\
Lepidobatrachus llanensis LL1 & -0.12498 & -0.625 & 0.1109 \\
Lepidobatrachus llanensis LL2 & $\mathbf{- 1 . 4 5 1 3 8}$ & $\mathbf{- 1 . 3 2 5}$ & 0.1863 \\
Lepidobatrachus llanensis LL3 & $\mathbf{- 1 . 6 9 1 1 3}$ & $\mathbf{- 1 5 . 4 8 4}$ & $\mathbf{0 . 0 6 6 2}$ \\
\hline
\end{tabular}

Note: Significant values $(p<0.05)$ in bold. Haplogroup names follow Fig. 3. Lepidobatrachus laevis L1 not included because it corresponds to a unique haplotype in the mitochondrial genealogy.

the species distribution (LL1). In contrast, all tests supported a recent population expansion scenario for L. laevis (L2) and L. llanensis haplogroups from the northern part of its distribution (LL2 and LL3, except for $R 2$ for LL2) (Table 4).

\subsection{Demographic history}

In EBSP analyses the "observation window" is delimited by the last coalescent event; some events, such as evolutionary bottlenecks, yield short coalescent times, which reduce the "observation window." Although with a recent sudden increases (about 1500 years), EBSP shows a mostly constant effective population sizes in both $L$. asper haplogroups, A1 (Fig. 5a) and A2 (Fig. 5b), with "observation windows" of 0.020 and $0.025 \mathrm{Ma}$, respectively. A sharp increase in population size was inferred for L. laevis L2 (Fig. 5c) in the last $0.25 \mathrm{Ma}$ after a long time of stability ("observation window" of $1.875 \mathrm{Ma}$ ). The southern L. llanensis haplogroup, LL1 (Fig. 5d), shows a short ("observation window" of $0.07 \mathrm{Ma}$ ) and constant demographic history, unlike LL2 (Fig. 5e), which shows a long ("observation window" of $5 \mathrm{Ma}$ ) and constant demographic history with a marked population-size increase $0.8 \mathrm{Ma}$ ago.

\subsection{Isolation-with-migration model}

According to IMa2 analyses, lineages of northern and southern $L$. llanensis diverged about $0.038 \mathrm{Ma}$ [95\% highest posterior density interval $(\mathrm{HPD})=0.019-0.071 \mathrm{Ma}$. After divergence, no evidence of migration was detected in any direction between the two populations. The estimate of effective population size was clearly higher for the northern populations.

\section{Discussion}

\subsection{Species tree: diversification time frame within Lepidobatrachus}

The results of the "Beast species tree suggests a Mid Miocene diversification in Lepidobatrachus with divergence times between species with high degree of overlap (Fig. 2). Diversification within Lepidobatrachus began with the L. asper split about 12.6 Ma (8.7-16.8 Ma 95\% HPD interval), followed by L. laevis-L. llanensis divergence about $9.7 \mathrm{Ma}$ (6.5-13.2 Ma 95\% HPD interval), both within the second half of the Miocene. The main event that occurred within this timeframe is the middle Miocene marine introgression into the Chaco and Paraná basins, called the Paranense Sea (Hernández et al., 2005). This marine introgression was the most important in size (see Hernández et al., 2005; Ottone et al., 2013) and occurred between 15 and 13 Ma (Hernández et al., 2005) with its final phases of regression estimated at about 8.7 Ma (Candela et al., 2012).

The Paranense Sea occupied a great portion of the current Chacoan distribution during the middle Miocene incursion. The extension of the sea in Argentinean Chaco covered Santa Fe, Formosa, and Chaco provinces, a great portion of Santiago del Estero, western and eastern borders of Córdoba, eastern border of Salta, and the east corner between Catamarca and La Rioja; in Paraguay only a small incursion was suggested, in southern Boquerón (Ottone et al., 2013). The northern and northeastern marine distribution reached the Michicola and Asunción archs, respectively (Hernández et al., 2005). The Michicola and Asunción archs are extensions of the Brazilian shield, a large subsurface that acts as a barrier of drainage systems (Lundberg et al., 1998). The distribution of the Paranense Sea suggests a strong influence on Lepidobatrachus diversification as a vicariant agent on widely distributed ancestral Chacoan populations. Furthermore, this distribution suggests the existence of possible refuges to the north, east, and south of the current Chaco during the Paranense Sea.

The Paranense Sea has previously been suggested as an important driver of diversification for other groups. Based on fossil faunas, Candela et al. (2012) suggested that the Paranense Sea acted as an important geographic barrier promoting vicariance between Mesopotamic and northwestern Patagonic faunas. Delsuc et al. (2012) dated the divergence between the two species of fairy armadillos (pichiciegos) at about $17 \mathrm{Ma}$ and suggested that the diversification was promoted by the disruption of the ancestral range, isolating populations to the south and north of the current Chaco. Finally, Morando et al. (2014) suggested that the three species groups of the gecko genus Homonota split by isolation of populations on emergent lands that surrounded the Paranense Sea. For species of Lepidobatrachus, we suggest that marine introgressions may have forced populations of a widely distributed ancestral species to become isolated in areas protected from flooding, which probably acted as refugia during marine introgressions; this condition might have favored opportunities for speciation by geographical isolation.

\subsection{Refugia during marine introgressions}

To suggest a refugium for $L$. asper is very difficult due to the poor sampling. Our sampling of $L$. asper covers only the southern portion of the known distribution of the species (Fig. 1b). Following Faivovich (1994), besides Córdoba, Santa Fe, and southern Santiago del Estero, the species has been recorded in Corrientes and Chaco provinces, and in the Paraguayan departments of Presidente Hayes and Alto Paraguay. Nevertheless, the last of these records is from 1980, and the species has never been found again in these latter localities. However, the low genetic diversity in both haplogroups (Table 2), and the short persistence time resulting from EBSP (Fig. 5A and B), may correspond to an evolutionary bottleneck, which suggests a Upper Pleistocene colonization of the southern Chaco, but as stated before, a better sampling is necessary to study the evolutionary history of this species.

Currently, L. llanensis shows a disjunct distribution with two population groups separated by an extensive gap in the province of Santiago del Estero, Argentina (Fig. 1d). Southern populations (LL1) exhibit lower genetic diversity and population structure than the northern populations (LL3) (Table 2; Fig. 3), which suggests a later colonization of the southern distribution. Paradoxically, the other northern 

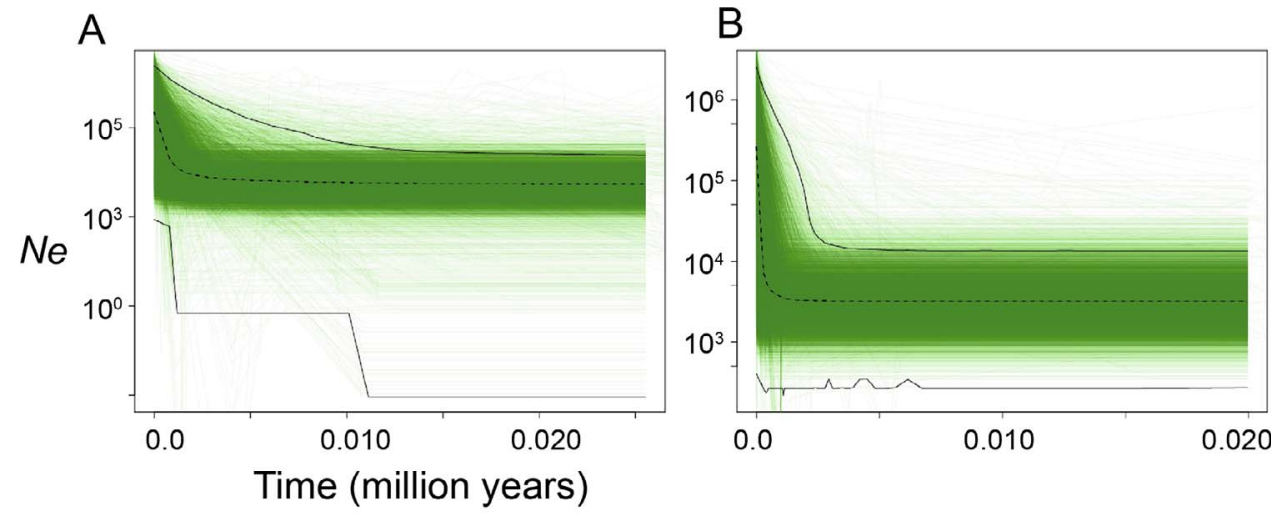

C
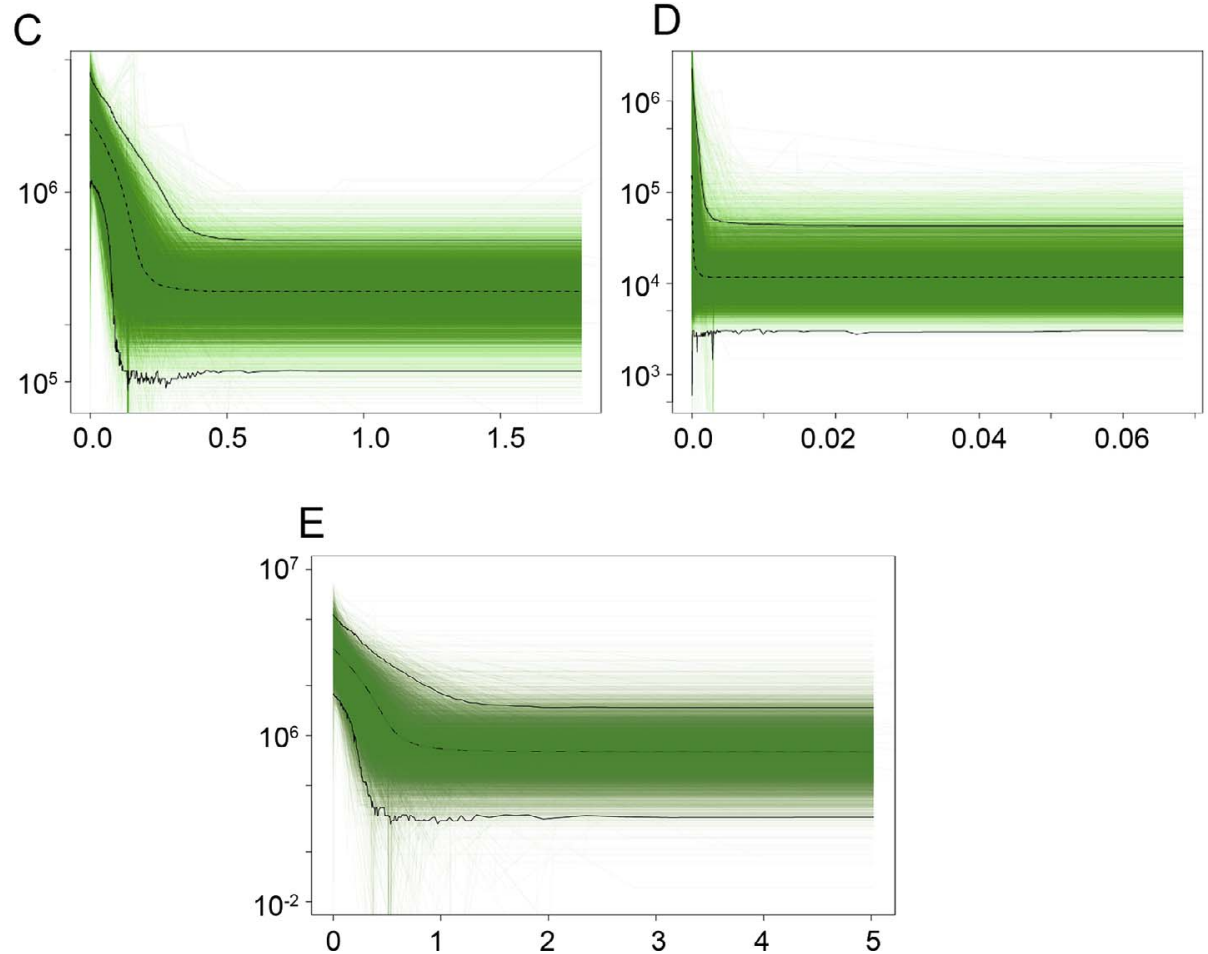

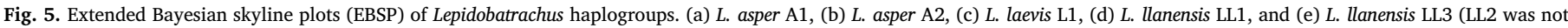

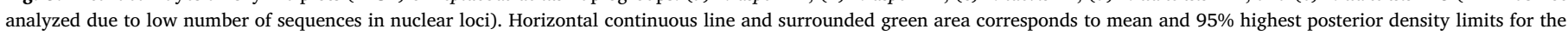

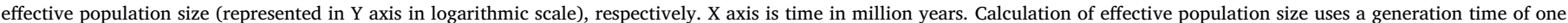
year. (For interpretation of the references to color in this figure legend, the reader is referred to the web version of this article.)

population (LL2) shows the lowest indices of genetic diversity (Table 2), and neutrality tests support a recent increase in population size (Table 4). This pattern suggests a later colonization by this lineage in the area, but with our current sampling the source of this colonization is not clear. EBSP analyses support a constant population history for the southern populations (LL1) and an expansion event for the northern LL3 (also supported by neutrality test, Table 4), although this expansion would not be very recent ( $0.8 \mathrm{Ma}$; Fig. 5e). Furthermore, EBSP analyses show a clearly longer time of persistence for northern LL3, with $5 \mathrm{Ma}$, than southern LL1 with only $0.07 \mathrm{Ma}$ (Fig. 5e and d, respectively), which supports the isolation of the L. llanensis ancestor in northern Chaco distribution, at areas protected by Michicola Arch (part of Boquerón in Paraguay and Salta in Argentina, and the Bolivian Chaco), an old structural arch that is present at least since the end of the Devonian (Salfity, 1982).

The sympatry between L. laevis and L. llanensis in the northern part of the Chaco distribution (Fig. 1) could have been the result of expansions of L. laevis from the east or the south. Haplotype genealogies with a repetitive star-like pattern (Fig. 3; Appendix C) support demographic expansions, following a population bottleneck, due to recent colonization (Slatkin and Hudson, 1991). The combination of high haplotype diversity $(\mathrm{Hd})$ and low nucleotide diversity $(\mathrm{Pi}$ ) (Table 2) also corresponds to population expansion after bottleneck events (Eizirik et al., 2001; Althoff and Pellmyr, 2002; Joseph et al., 2002; Stamatis et al., 2004). High values of haplotype diversity and low nucleotide diversity result from an accumulation of mutations, which consequently results in a high number of closely related haplotypes (i.e. many recently evolved haplotypes). Neutrality tests also support expansion events in L. laevis (Table 4) with a sudden increase of the population size in the last $0.25 \mathrm{Ma}$ (Fig. 5c), which reinforce the idea of the absence of a northern refugium for the L. laevis ancestor.

Besides areas protected by Michicola Arch, other putative refugia are located in the east and southeast of the current Chaco distribution. The Paranense Sea covered a massive land surface in southern South America, flooding all lowlands between old archs and cratons, such as Asunción and Michicola archs, and Brazilian and Rio de la Plata cratons (Fig. 6). A fossil of a recently described species of Lepidobatrachus (Nicoli, 2015) was found at Farola Monte Hermoso, province of Buenos Aires (Tomassini et al., 2011). This locality corresponds to Rio de la Plata Craton. Other fossils related to some species currently restricted to 


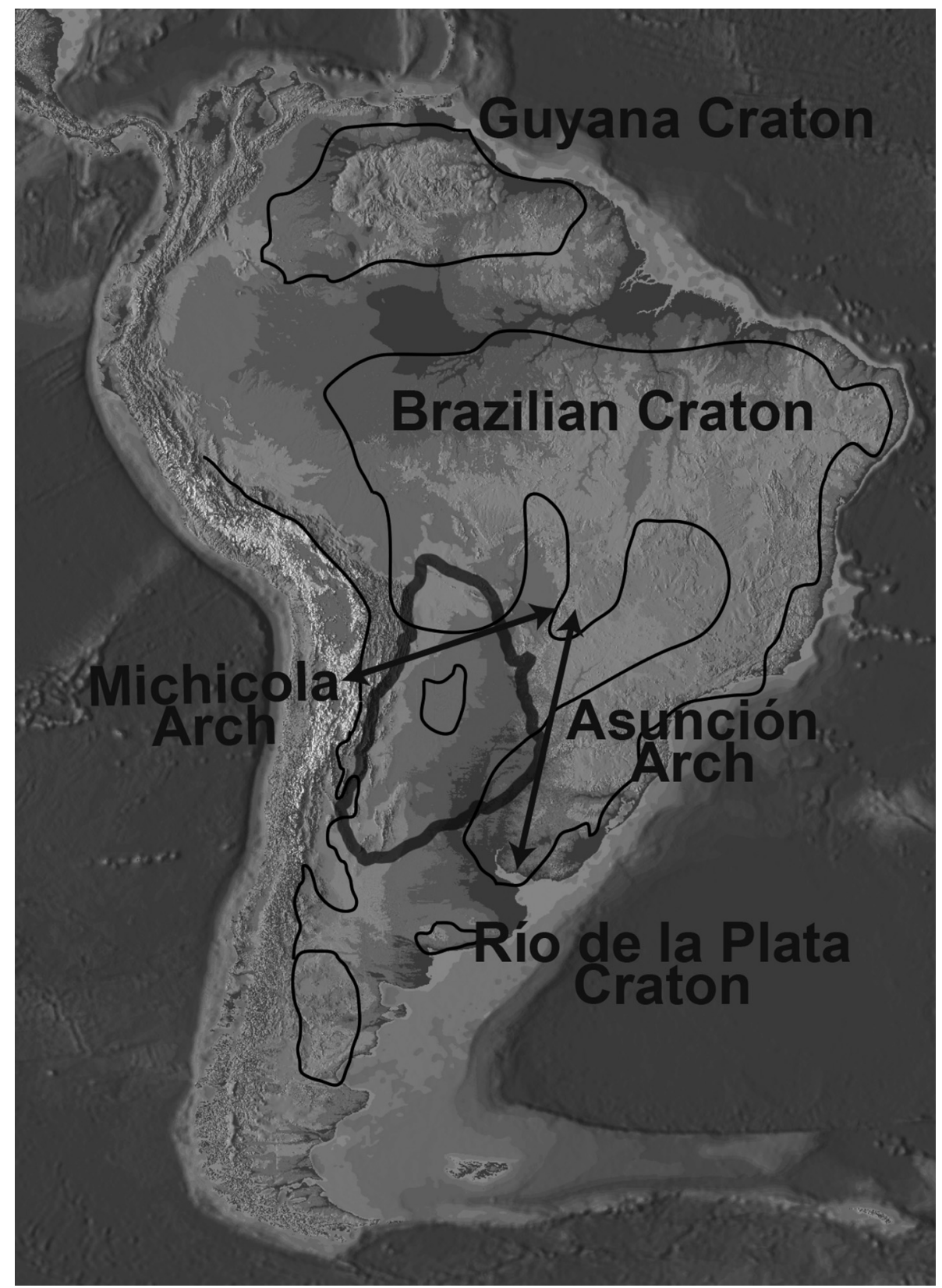

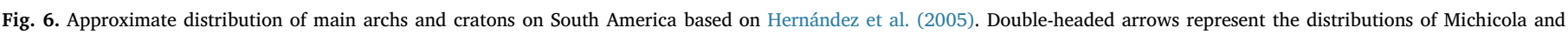
Asunción archs. Area enclosed in thick black denotes the limits of the Chaco biome.

Chaco wooded areas were also recovered at Farola Monte Hermoso (Tonni, 1974; Tomassini et al., 2011; Nicoli, 2015), supporting the idea that at least until the Pliocene, the climatic conditions on Farola Monte Hermoso were similar to those of the current Chaco (Tonni, 1974; Pascual, 1984; Pascual et al., 1996). Nicoli (2015) questioned some of the paleoecological inferences of these authors, especially those based on the presence of fossils of widely distributed species (extant or extinct), which occur in other regions besides the Chaco. However, the presence of fossils of species that currently are not restricted to the Gran Chaco is not ultimate evidence that Farola Monte Hermoso was not similar to the current Chaco.

Another putative refugium for Chacoan fauna during marine introgressions is the Asunción Arch. This formation protected a large land surface during the middle-Miocene marine introgressions and covers parts of southern Paraguay southward along Misiones, Corrientes, and Entre Ríos provinces in Argentina (Hernández et al., 2005). Fossil records from the Hermanderías y El Bretela deposit (Entre Ríos province) support the domination of Chacoan-like xerophilous wood paleo-communities at least until the Pliocene (Hinojosa and Villagrán, 1997). Furthermore, several authors suggested that climatic changes generated by the final uplift of the Andes and the influence of the Humboldt Current caused expansions of xeric vegetation over an extensive area of southern South America during the middle-late Miocene and Pliocene (Solbrig et al., 1977; Axelrod, 1979; Landrum, 1981; Arroyo et al., 1995).

Isolated populations of the Lepidobatrachus ancestor in the southern and/or southwestern parts of the current Chaco distribution are plausible, because no evidence supports marine flooding in this part of the region, which would be southeastern La Rioja, central and southern Córdoba, and northwestern San Luis (Ottone et al., 2013). However, our data suggest a recent colonization of southwestern Chaco by $L$. llanensis from the northern part of its distribution and a short persistence of $L$. asper in the southern Chaco. The southern distribution of the Gran Chaco has been influenced by Pleistocene glaciations (Ortiz- 
Jaureguizar and Cladera, 2006). Climatic and environmental changes associated with glaciation events caused cyclic distributional shifts of southern biomes, including the Chaco (Cosacov et al., 2010; OrtizJaureguizar and Cladera, 2006). Furthermore, during these glaciations, a narrow area of very arid conditions, called the "Arid Diagonal," was distributed from the Atlantic coast of Patagonia (Chubut, Argentina) to western-central Gran Chaco (Tucumán, Argentina) (Cosacov et al., 2010), reaching La Rioja, Catamarca, and southwestern Santiago del Estero (southwestern Chaco). These events may have masked any genetic signature produced by southern refugia during marine introgressions by local extinctions in the southern Chaco during the Pleistocene.

\subsection{Genetic structure and putative dispersal barriers within the Chaco}

STRUCTURE analyses recovered only the three species $(\mathrm{K}=3$; Fig. 4) without any genetic break within them. However, at $K=5$ a shallow differentiated deme was evident, which gradually increased in differentiation to $\mathrm{K}=8$, where it was most evident. This deme corresponds to the mitochondrial haplogroup A1 (Fig. 3a), which groups all L. asper individuals from Santa Fe (Fig. 1b). The other L. asper haplogroup (A2; Fig. 3a) groups together all individuals from Córdoba and Santiago del Estero (Fig. 1b). Although we only partially sampled $L$. asper, this genetic structure is remarkable since the three sampled localities are almost equidistant to each other and because the last foothills of the Sierras Chicas formations are located between the localities of Córdoba and Santiago del Estero (Fig. 1a). Besides geographic distance, two rivers present between A1 and A2 may act as barriers, the Salado and the Dulce rivers (Fig. 1a). Populations corresponding to the A1 and A2 haplogroups have little or no gene flow $(F s t=0.911)$ but low genetic differentiation $(D a=0.014)$, which suggest a recent divergence. EBSP results support a Pleistocene divergence with low persistence time of both $\mathrm{A} 1$ and $\mathrm{A} 2$, and also show constant population histories (Fig. 5a and b), as expected for diversification by barriers without cycles of extinctions and expansions (Amaral et al., 2013). The recent divergence between A1 and A2 may correspond to the dynamics of the Salado and Dulce rivers. During the Quaternary, the Chaco experienced climatic changes oscillating between dry and humid periods (Iriondo, 1993; Iriondo and García, 1993; de Vivo and Carmignotto, 2004). In dry periods these allochthonous rivers, like the other main Chacoan rivers (Pilcomayo and Bermejo), were ephemeral with highly seasonal channels. Only between the last glacial maximum (21,000 years ago) and the late Holocene were two dry periods identified (Iriondo, 1993; Iriondo and García, 1993). However, without better sampling we cannot confidently assess the influence of rivers or any other putative barrier on genetic structure within $L$. asper.

We detected some structure in the L. llanensis mitochondrial genealogy, which is concordant with the geographical distribution of the specimens and suggests some breaks in the landscape. The main break within this species corresponds to a gap of about $400 \mathrm{~km}$ in central Santiago del Estero province, Argentina, separating southern L. llanensis populations (LL1) from northern populations (LL2 and LL3) (Figs. 1d and $3 a$ ). Between the southern and each northern haplogroup we found a relatively high level of differentiation (Fst range from 0.63 to 0.94 ) and genetic distance ( $D a$ range from 0.008 to 0.017) (values for Fst and $D a$ in Table 3). This distribution gap may not simply correspond to a sampling gap, since there are no historical records of the species, and it matches the southern and/or western distributional limits of other Chacoan species (e.g. L. laevis, Scinax acuminatus, Melanophryniscus klappenbachi and Physalaemus cuqui). Furthermore, another endemic species with a distribution similar to that of L. llanensis, Chacophrys pierottii, shows a comparable spatial differentiation pattern. This gap corresponds to a high-temperature area called the "South American heat pole" (Prohaska, 1959) with summer temperatures of about $47^{\circ} \mathrm{C}$. Furthermore, a low-precipitation regime (Boletta, 1989) and high salinity (Ruibal, 1962) are important environmental characteristics of this area, and may act as a climatic barrier to L. llanensis dispersal, and that of other anuran species as well. This disjunct distribution could also be associated with recent local extinctions caused by landscape changes due to severe logging and ranching since early last century in this region of Argentina (Bucher and Huszar, 1999). However, IMa2 splitting time between southern and northern sampled sites of L. llanensis (HPD 95\% $=0.019-0.071 \mathrm{Ma}$ ), which corresponds to the Pleistocene, seems to be much older than the Santiago del Estero anthropic landscape transformation.

South American Upper Pleistocene is marked by increasing increments of temperature and drier conditions (Ortiz-Jaureguizar and Cladera, 2006), which may have increased seasonality and extreme conditions of central Santiago del Estero. Lepidobatrachus llanensis, as a Chacoan pond-breeding amphibian, depends on the availability of lentic aquatic habitats, which in regions with low precipitation and high temperatures are very scarce and isolated (Lescano et al., 2015). Isolated populations have smaller population sizes with lower genetic diversity, which reduces evolutionary potential and consequently increases the risk of extinction (Reed and Frankham, 2003; Funk et al., 2005). Besides the low availability of habitats, extremely high temperatures could be lethal for frogs, both in adult and larval stages (Wells, 2007). Duarte et al. (2012), studying tadpoles of a population of Formosa (Argentina), north of the Santiago del Estero gap, found a relatively high thermal tolerance for $L$. llanensis (critical thermal limit, $C T_{\max }=44.7^{\circ} \mathrm{C}$ ); however, this limit is only slightly higher than the maximum pond temperatures. Furthermore, for the congeneric L. laevis, Carroll (1996) found low tadpole survival rates for short-time thermal shocks of $45^{\circ} \mathrm{C}$. The thermal tolerance of L. llanensis, although relatively high, may not be enough for the survival of this species in the extremely high temperatures of the central region of Santiago del Estero, at least since the Upper Pleistocene. We suggest that the combination of low precipitation and high temperatures could be responsible for making this area an impermeable barrier to L. llanensis dispersal. The idea of a climatic barrier in central Santiago del Estero is also supported by the IMa2 results, without any evidence of migration between the two population groups after divergence.

We found the genetic structure of L. llanensis to be more related to rivers than that of L. laevis (Fig. 3B and C). In L. laevis, genetic evidence suggests a recent colonization of the area of influence of Pilcomayo and Bermejo rivers and, therefore, a shorter evolutionary history than $L$. llanensis, which has older populations and longer persistence in this region of the Chaco. The lower genetic structure of L. laevis in the Pilcomayo and Bermejo area of influence is possibly related to the late Quaternary history of these rivers, with ephemeral and highly seasonal channels that did not serve as an effective barrier. While L. laevis experienced recent expansions from southern regions due to lack of dispersal barriers, the Pilcomayo and Bermejo rivers have influenced the distribution of L. llanensis populations for a long time. The dynamics of Pilcomayo and Bermejo rivers shaped a complex genetic pattern on $L$. llanensis populations due to its long persistence in this region. Watervolume differences between dry and humid periods, and the changing watercourses, caused recurrent connections and disconnections between populations of both sides of these rivers, promoting short and intermittent vicariant events. In dynamic systems like this, a population may split into several populations or may join with others, as well as vary in size, density and location (Hey and Machado, 2003).

The Paraguay River is the largest river analyzed here and unlike the other rivers, it does not cross the Chaco in a west-east direction. Of the species of Lepidobatrachus, only L. asper was known from the oriental margin of the Paraguay River (Corrientes Province, Argentina), but without new records since early 1980s (see Faivovich, 1994). Recently, Sugai et al. (2013) cited L. laevis (as L. asper) from Patolá Farm, Porto Murtinho, a Chacoan fragment in the southwestern part of Mato Grosso do Sul state, in central Brazil, at the other margin of the river. We included four individuals from this locality yielding three haplotypes, including two exclusives but separated by only one and two mutations from individuals from the Central Paraguayan Chaco (occidental 
margin of the Paraguay River) and one shared with them (Fig. 3c). This lack of genetic structure suggests constant gene flow among populations from both sides of this river. Frutos and Van Den Bussche (2002) found similar results in armadillo populations from both sides of this river. Although this river is the distributional limit for some small mammals, it is probably not acting as an impassable barrier, but different soil structures and compositions determine different habitats on each side of the river (Myers, 1982). However, the southwestern region of Mato Grosso do Sul, Brazil, where it was registered and is the only known record of L. laevis east of the river, is also considered part of the Chaco (see Souza et al., 2010). Based on analyses of water-level records of the upper Paraguay River, Collischonn et al. (2001) found that between 1960 and 1972 an abrupt water level decrease occurred. This kind of event may have continuously permitted connection between L. laevis populations from both sides of this river. However, we do not discard the contribution of vegetation rafting to the connectivity between west and east bank populations. Two records of $L$. laevis from riverine localities (west bank) are known from Paraguay (Faivovich, 1994), one of them on the bank just opposite the only known record from the east bank in Brazil. We suggest that heavy rains may carry some individuals (tadpoles or adults) to the river through small temporary streams, and that some of them are capable of crossing the river on vegetation rafts. In a similar situation, several anurans from three different families were recovered from vegetation rafts in an Amazonian river (Schiesari et al., 2003) and in the Paraná River (Achaval et al., 1979).

\section{Conclusions}

Based on a fossil-calibrated species tree, we suggest an important role of the middle Miocene marine introgression as a driver of diversification of Lepidobatrachus. This internal sea covered a great expanse of lowlands in southern South America between old archs and cratons and may have acted as a barrier to transgression. Population structure, patterns of genetic diversity and historical demography data suggest that these archs and cratons were probably suitable refugia during marine introgressions, and thus favored speciation by geographic isolation. We also found some genetic structure within Lepidobatrachus species, which could be associated with some breaks in the landscape. The main break corresponds to an area of high aridity in central Chaco, which caused a disjunct distribution for L. llanensis, with two population groups. Results from the isolation-migration (IMa2) analyses, without any evidence of migration between the two population groups after divergence, also supports the idea of a barrier in this region. We also found some influences by the main rivers, which due to their historical dynamics might have promoted short and intermittent vicariant events, allowing recurrent connections among populations of both sides of the rivers.

\section{Acknowledgements}

We thank Franco L. de Souza (ZUFMS) and Julián Faivovich (MACN) for making available tissue samples under their care; to Julián Lescano and Boris Blotto for sample collections; and to Juan Boeris, Jimena Grosso, Julián Faivovich, and Tereza Thomé for their help during fieldwork. We are very grateful to the owners of the Teniente Prieto, Aguada Siete and Chaco Boef farms for allowing access to their properties, and especially to the owners of Salazar, Montana, Cotorrita and Toro Retá farms, which besides access, also provided accommodation during fieldwork. For making contact with farm owners and continually providing all kinds of support during fieldwork, we are especially thankful to Francisco Brusquetti Frutos, Alejandra Brusquetti and Luis Vargas. We thank the Secretaría del Ambiente del Paraguay (SEAM, Paraguay) for collection permits and for the access and accommodation in Teniente Enciso and Defensores del Chaco national parks. We also thank Thais Condez for comments and suggestions that helped to improve the manuscript, and Zunilda Sisa for her valuable help with English. This research was supported by resources supplied by the Center for Scientific Computing (NCC/GridUNESP) of the São Paulo State University (UNESP) and by Conselho Nacional de Desenvolvimento Científico e Tecnológico (CNPq, Brazil), grant \#472463/2012-8 to CFBH. FB and FN thank Programa Nacional de Incentivo a Investigadores from the Consejo Nacional de Ciencia y Tecnología (PRONII, CONACYT, Paraguay), for financial support, and FB also thanks Coordenação de Aperfeiçoamento de Pessoal de Nível Superior (CAPES, Brazil), Programa de Estudantes-Convênio de PósGraduaçao (PEC-PG), for a fellowship. DB is grateful to FONCyT (PICT 2011/1524, 2011/1895, 2012/2687, 2013/0404, 2014/1343, 2014/ 1930, 2014/2035, 2015/0813, 2015/0820, 2015/2381), and CONICET (PIP 112201101/00875), for financial support. CFBH thanks grant \#2013/50741-7 São Paulo Research Foundation (FAPESP) and a research fellowship of CNPq.

\section{Appendix A. Supplementary material}

Supplementary data associated with this article can be found, in the online version, at https://doi.org/10.1016/j.ympev.2018.02.010.

\section{References}

Achaval, F., González, J.G., Meneghel, M., Melgarejo, A.R., 1979. Lista comentada del material recogido en costas uruguayas, transportado por camalotes desde el Río Paraná. Acta Zool. Lilloana 35, 195-199.

Agnolín, F., 2012. A new Calyptocephalellidae (Anura, Neobatrachia) from the upper Cretaceous of Patagonia, Argentina, with comments on its systematic position. Studia Geol. Salmant. 48, 129-178.

Althoff, D.M., Pellmyr, O., 2002. Examining genetic structure in a Bogus yucca moth: a sequential approach to phylogeography. Evolution 56, 1632-1643. http://dx.doi. org/10.1554/0014-3820(2002) 056[1632:EGSIAB]2.0.CO;2.

Amaral, F.R., Albers, P.K., Ewards, S.V., Miyaki, C.Y., 2013. Multilocus tests of Pleistocene refugia and ancient divergence in a pair of Atlantic forest antbirds (Myrmeciza). Mol. Ecol. 22, 3996-4013. http://dx.doi.org/10.1111/mec.12361.

Arroyo, M.T.K., Cavieres, L., Marticorena, C., Muñoz-Schick, M., 1995. Convergence in the mediterranean floras in central Chile and California: insights from comparative biogeography. In: Arroyo, M.T.K., Zedler, P., Fox, M. (Eds.). Ecology and Biogeography of Mediterranean Ecosystem in Chile, California and Australia. Ecol. Stud. 108, 43-88. Springer-Verlag, New York. http://doi.org/10.1007/978-1-46122490-7_3.

Axelrod, D., 1979. Desert vegetation, its age and origin. In: Goodin, J.R., Northington, D.K. (Eds.), Arid Land Resources. Int. Cent. Arid and Semi-arid Land Stud. Texas University, Lubbock, Texas, pp. 1-72.

Báez, A.M., Perí, S., 1989. Baurubatrachus pricei, nov. gen. et sp., un anuro del Cretácico Superior de Minas Gerais, Brasil. An. Acad. Bras. Ciênc. 61, 447-458.

Báez, A.M., Muzzopappa, P., Nicoli, L., 2005. The Late Cretaceous neobatrachian frog Baurubatrachus revisited. In: II Congreso Latinoamericano de Paleontología de Vertebrados, Boletim de Resumos. Rio de Janeiro, Brasil, 10-12 August 2005. Museo Nacional, Rio de Janeiro, Brasil, pp. 45-46.

Bell, R.C., MacKenzie, J.B., Hickerson, M.J., Chavarría, K.L., Cunningham, M., Williams, S., Moritz, C., 2011. Comparative multi-locus phylogeography confirms multiple vicariance events in co-distributed rainforest frogs. Proc. R. Soc. Lond. Ser. B: Biol. Sci. 279, 991-999. http://dx.doi.org/10.1098/rspb.2011.1229.

Blotto, B.L., Nuñez, J.J., Basso, N.G., Úbeda, C.A., Wheeler, W.C., Faivovich, J., 2013. Phylogenetic relationships of a Patagonian frog radiation, the Alsodes + Eupsophus clade (Anura: Alsodidae), with comments on the supposed paraphyly of Eupsophus. Cladistics 113-131. http://dx.doi.org/10.1111/j.1096-0031.2012.00417.x.

Boletta, P.E., 1989. Clima. In: Casas, R.R. Desmonte y habilitación de tierras en la Región Chaqueña Semiárida. FAO Oficina Regional FAO para América Latina y el Caribe, Red de Cooperación Técnica en usos de los Recursos Naturales en la Región Chaqueña Semiárida Argentina-Bolivia-Paraguay. Santiago, Chile, pp. 7-21.

Bouckaert, R.R., Heled, J., Kühnert, D., Vaughan, T., Wu, C., Xie, D., Suchard, M.A., Rambaut, A., Drummond, A.J., 2014. Beast 2: a software platform for Bayesian evolutionary analysis. PLoS Comput. Biol. 10 (4), e1003537. http://dx.doi.org/10. 1371/journal.pcbi.1003537.

Bouckaert, R.R., 2015. bModelTest: Bayesian Site Model Selection for Nucleotide Data. <http://biorxiv.org/content/biorxiv/early/2015/06/11/020792.full.pdf >

Bucher, E.H., 1982. Chaco and Caatinga - South American arid savannahs, woodland and thickets. In: Huntley, B.J., Walker, B.H. (Eds.), Ecology of Tropical Savannahs. Ecol. Stud. 42, 48-79. Springer-Verlag, New York.

Bucher, E.H., Huszar, P.C., 1999. Sustainable management of the Gran Chaco of South America: ecological promise and economic constraints. J. Environ. Manage. 57, 99-108. http://dx.doi.org/10.1006/jema.1999.0290.

Cabrera, A.L., 1994. Regiones fitogeográficas Argentinas, Enciclopedia Argentina de Agricultura y Jardinería, Primera Reimpresión, Volume 2. Editorial Acme, Buenos Aires, 85 pp.

Cabrera, A.L., Willink, A., 1973. Biogeografía de América Latina. Monografia 13, Serie de Biología. OEA, Washington, D.C. 
Candela, A.M., Bonini, R., Noriega, J.I., 2012. First continental vertebrates from the marine Paraná Formation (late Miocene, Mesopotamia, Argentina): chronology, biogeography and palaeoenvironments. Geobios 45, 515-526. http://dx.doi.org/10. 1016/j.geobios.2012.05.003.

Carroll Jr., E.J., 1996. Thermal tolerance and heat shock protein synthesis during development in the anuran Lepidobatrachus laevis. Dev.Growth Differ. 38, 9-14. http:// dx.doi.org/10.1046/j.1440-169X.1996.00002.x.

Casamiquela, R.M., 1963. Sobre un par de anuros del Mioceno de Río Negro (Patagonia) Wawelia gerholdi n-gen et sp. (Ceratophrydae) y Gigantobatrachus parodii (Leptodactylidae). Ameghiniana 5, 141-162.

Cione, A.L., Tonni, E.P., Bargo, S., Bond, M., Candela, A.M., Carlini, A.A., Deschamps, C. M., Dozo, M.T., Esteban, G., Goin, F.J., Montalvo, C.I., Nasif, N., Noriega, J.I., OrtizJaureguizar, E., Pascual, R., Prado, J.L., Reguero, M.A., Scillato-Yané, G.J., Soibelzon, L., Verzi, D.H., Vieytes, E.C., Vizcaíno, S.F., Vucetich, M.G., 2007. Mamíferos continentales del Mioceno tardío a la actualidad en la Argentina: cincuenta años de estudios. Asociación Paleontológica Argentina. Publicación Especial 11, Ameghiniana $50^{\circ}$ aniversario pp. 257-278.

Collischonn, W., Tucci, C.E.M., Clarke, R.T., 2001. Further evidence of changes in the hydrological regime of the river Paraguay: part of a wider phenomenon of climate change? J. Hydrol. 245, 218-238. http://dx.doi.org/10.1016/S0022-1694(01) 00348-1.

Cosacov, A., Sérsic, A.N., Sosa, V., Johnson, L.A., Cocucci, A.A., 2010. Multiple periglacial refugia in the Patagonian steppe and post-glacial colonization of the Andes: the phylogeography of Calceolaria polyrhiza. J. Biogeogr. 37, 1463-1477. http://dx.doi. org/10.1111/j.1365-2699.2010.02307.x.

Delsuc, F., Superina, M., Tilak, M., Douzery, E.J.P., Hassanin, A., 2012. Molecular phylogenetics unveils the ancient evolutionary origins of the enigmatic fairy armadillos. Mol. Phylogenet. Evol. 62, 673-680. http://dx.doi.org/10.1016/j.ympev.2011.11. 008.

de Vivo, M., Carmignotto, A.P., 2004. Holocene vegetation change and the mammal faunas of South America and Africa. J. Biogeogr. 31, 943-957. http://dx.doi.org/10. 1111/j.1365-2699.2004.01068.x.

Dinerstein, E., Olson, D.M., Graham, D.J., Webster, A.L., Primm, S.A., Bookbinder, M.P., Ledec, G., 1995. A Conservation Assessment of the Terrestrial Ecoregions of Latin America and the Caribbean. World Bank, Washington (DC)

Duarte, H., Tejedo, M., Katzenberger, M., Marangoni, F., Baldo, D., Beltrán, J.F., Martí, D.A., Richter-Boix, A., Gonzalez-Voyer, A., 2012. Can amphibians take the heat? Vulnerability to climate warming in subtropical and temperate larval amphibian communities. Glob. Change Biol. 18, 412-421. http://dx.doi.org/10.1111/j.13652486.2011.02518.x.

Duellman, W.E., 1999. Distribution patterns of amphibians in South America. In: Duellman, W.E. (Ed.), Patterns of Distribution of Amphibians: a Global Perspective. John Hopkins University Press, Baltimore, Maryland.

Drummond, A.J., Bouckaert, R.R., 2015. Bayesian Evolutionary Analysis with Beast 2. Cambridge University Press Available at: < http://beast2.org/book.html $>$.

Earl, D.A., 2012. STRUCTURE HARVESTER: a website and program for visualizing STRUCTURE output and implementing the Evanno method. Conserv. Genet. Resour. 4, 359-361. http://dx.doi.org/10.1007/s12686-011-9548-7.

Edgar, R.C., 2004. MUSCLE: multiple sequence alignment with high accuracy and high throughput. Nucl. Acids Res. 32, 1792-1797. http://dx.doi.org/10.1093/nar/ gkh340.

Eizirik, E., Kim, J.H., Menotti-Raymond, M., Crawshaw Jr., P.G., O’Brien, S.J., Johnson, W.E., 2001. Phylogeography, population history and conservation genetics of jaguars (Panthera onca, Mammalia, Felidae). Mol. Ecol. 10, 65-79. http://dx.doi.org/10. 1046/j.1365-294X.2001.01144.x.

Evans, S.E., Jones, M.E.H., Krause, D.W., 2008. A giant frog with South American affinities from the Late Cretaceous of Madagascar. Proc. Natl. Acad. Sci. U.S.A. 105 2951-2956. http://dx.doi.org/10.1073/pnas.0707599105.

Fabrezi, M., Quinzio, S.I., 2008. Morphological evolution in Ceratophryinae frogs (Anura, Neobatrachia): the effects of heterochronic changes during larval development and metamorphosis. Zool. J. Linn. Soc. 154, 752-780. http://dx.doi.org/10.1111/j.10963642.2008.00420.x.

Faivovich, J., 1994. La distribución del género Lepidobatrachus Budgett, 1899 (Leptodactylidae: Ceratophryinae). Acta Zool. Lilloana 43, 105-115.

Faivovich, J., Nicoli, L., Blotto, B.L., Pereyra, M.O., Baldo, D., Barrionuevo, J.S., Fabrezi, M., Wild, E.R., Haddad, C.F.B., 2014. Big, bad, and beautiful: phylogenetic relationships of the Horned Frogs (Anura: Ceratophryidae). South Am. J. Herpetol. 9, 207-227. http://dx.doi.org/10.2994/SAJH-D-14-00032.1.

Felsenstein, J., 2005. PHYLIP (Phylogeny Inference Package) Version 3.6. Distributed by the Author. Department of Genome Sciences, University of Washington, Seattle, WA.

Fernicola, J.C., 2001. Una nueva especie de Ceratophrys (Anura, Leptodactylidae) en el Neógeno de la provincia de Buenos Aires, Argentina. Ameghiniana 38, 385-391.

Frazão, A., Silva, H.R., Russo, C.A.M., 2015. The Gondwana breakup and the history of the Atlantic and Indian Oceans unveils two new clades for early neobatrachian diversification. Plos One 10, e0143926. http://dx.doi.org/10.1371/journal.pone. 0143926.

Freilich, X., Tollis, M., Boissinot, S., 2014. Hiding in the highlands: evolution of a frog species complex of the genus Ptychadena in the Ethiopian highlands. Mol. Phylogenet. Evol. 71, 157-169. http://dx.doi.org/10.1016/j.ympev.2013.11.015.

Frutos, S.D., Van Den Bussche, R.A., 2002. Genetic diversity and gene flow in nine-banded armadillos in Paraguay. J. Mammal. 83, 815-823. http://dx.doi.org/10.1644/15451542(2002) $083<0815:$ GDAGFI > 2.0.CO;2.

Fu, Y.X., 1997. Statistical tests of neutrality of mutations against population growth, hitchhiking and background selection. Genetics 147, 915-925.

Funk, W.C., Greene, A.E., Corn, P.S., Allendorf, F.W., 2005. High dispersal in a frog species suggests that it is vulnerable to habitat fragmentation. Biol. Lett. http://dx. doi.org/10.1098/rsbl.2004.0270. 13e16.

Gregory-Wodzicki, K.M., 2000. Uplift history of the Central and Northern Andes: a review. Geol. Soc. Am. Bull. 112, 1091-1105.

Hasegawa, M., Kishino, H., Yano, T., 1985. Dating of the human-ape splitting by a molecular clock of mitochondrial DNA. J. Mol. Evol. 22, 160-174.

Heinicke, M.P., Duellman, W.E., Trueb, L., Means, D.B., MacCulloch, R.D., Hedges, S.B. 2009. A new frog family (Anura: Terrarana) from South America and an expanded direct-developing clade revealed by molecular phylogeny. Zootaxa 2211, 1-35. http://dx.doi.org/10.5281/zenodo.189873.

Heled, J., Drummond, A.J., 2008. Bayesian inference of population size history from multiple loci. BMC Evol. Biol. 8, 289. http://dx.doi.org/10.1186/1471-2148-8-289.

Heled, J., Drummond, A.J., 2010. Bayesian inference of species trees from multilocus data. Mol. Biol. Evol. 27, 570-580. http://dx.doi.org/10.1093/molbev/msp274.

Hernández, R.M., Jordan, T.E., Farjat, A.D., Echavarria, L., Idleman, B.D., Reynolds, J.H., 2005. Age, distribution, tectonics, and eustatic controls of the Paranense and Caribbean marine transgressions in southern Bolivia and Argentina. J. South Am. Earth Sci. 19, 495-512. http://dx.doi.org/10.1016/j.jsames.2005.06.007.

Hey, J., 2010. Isolation with migration models for more than two populations. Mol. Biol. Evol. 27, 905-920. http://dx.doi.org/10.1093/molbev/msp296.

Hey, J., Machado, C.A., 2003. The study of structured populations new hope for a difficult and divided science. Nat. Rev. Genet. 4, 535-543. http://dx.doi.org/10.1038/ nrg1112.

Hey, J., Nielsen, R., 2007. Integration within the Felsenstein equation for improved Markov chain Monte Carlo methods in population genetics. Proc. Natl. Acad. Sci. U.S.A. 104, 2785-2790. http://dx.doi.org/10.1073/pnas.0611164104.

Hewitt, G.M., 1996. Some genetic consequences of the ice ages, and their role in divergence and speciation. Biol. J. Linn. Soc. 58, 247-276. http://dx.doi.org/10.1111/j. 1095-8312.1996.tb01434.x.

Huson, D.H., Bryant, D., 2006. Application of phylogenetic networks in evolutionary studies. Mol. Biol. Evol. 23, 254-267. http://dx.doi.org/10.1093/molbev/msj030.

Hinojosa, L.F., Villagrán, C., 1997. Historia de los bosques del sur de Sudamérica, I: antecedentes paleobotánicos, geológicos y climáticos del Terciario del cono sur de América. Rev. Chil. Hist. Nat. 70, 225-239.

Iriondo, M., 1993. Geomorphology and late quaternary of the Chaco (South America) Geomorphology 7, 289-303. http://dx.doi.org/10.1016/0169-555X(93)90059-B.

Iriondo, M.H., García, N.O., 1993. Climatic variations in the Argentine plains during the last 18,000 years. Palaeogeogr. Palaeoclimatol. Palaeoecol. 101, 209-220. http://dx. doi.org/10.1016/0031-0182(93)90013-9.

The IUCN Red List of Threatened Species. Version 2017-1. < http://www.iucnredlist. org $>$ (Downloaded on 13 June 2017)

Jakobsson, M., Rosenberg, N.A., 2007. CLUMPP: a cluster matching and permutation program for dealing with label switching and multimodality in analysis of population structure. Bioinformatics 23, 1801-1806. http://dx.doi.org/10.1093/bioinformatics/ btm233.

Joseph, L., Wilke, T., Alpers, D., 2002. Reconciling genetic expectations from host specificity with historical population dynamics in an avian brood parasite, Hosrefield's Bronze-Cuckoo Chalcites basalis of Australia. Mol. Ecol. 11, 829-837. http://dx.doi. org/10.1046/j.1365-294X.2002.01481.x.

Jungfer, K.H., Faivovich, J., Padial, J.M., Castroviejo-Fisher, S., Lyra, M.L., Berneck, B.V.M., Iglesias, P.P., Kok, P.J.R., MacCulloch, R.D., Rodrigues, M.T., Verdade, V.K., Torres Gastello, C.P., Chaparro, J.C., Valdujo, P.H., Reichle, S., Moravec, J., Gvozdik, V., Gagliardi-Urrutia, G., Ernst, R., De la Riva, I., Means, D.B., Lima, A.P., Senaris, C.J., Wheeler, W.C., Haddad, C.F.B., 2013. Systematics of spiny-backed treefrogs (Hylidae: Osteocephalus): an Amazonian puzzle. Zool. Scr. 42, 351-380. http://dx.doi. org $/ 10.1111 /$ zsc. 12015

Kimura, M., 1969. The number of heterozygous nucleotide sites maintained in a finite population due to steady flux of mutations. Genetics 61, 893-903.

Landrum, L., 1981. The phylogeny and geography of Myrceugenia (Myrtaceae). Brittonia 33, 105-129.

Langone, J.A., Camargo, A., de Sá, R.O., 2016. High genetic diversity but low population structure in the frog Pseudopaludicola falcipes (Hensel, 1867) (Amphibia, Anura) from the Pampas of South America. Mol. Phylogenet. Evol. 95, 137-151. http://dx.doi. org/10.1016/j.ympev.2015.11.012.

Lescano, J.N., Bellis, L.M., Hoyos, L.E., Leynaud, G.C., 2015. Amphibian assemblages in dry forests: multi-scale variables explain variations in species richness. Acta Oecol. 65-66, 41-50.

Librado, P., Rozas, J., 2009. DnaSP v5: a software for comprehensive analysis of DNA polymorphism data. Bioinformatics 25, 1451-1452. http://dx.doi.org/10.1093/ bioinformatics/btp187.

Lundberg, J.G., Marshall, L.G., Guerrero, J., Horton, B., Malabarba, M.C.S.L., Wesselingh, F., 1998. The stage for Neotropical fish diversification: a history of tropical South American rivers. In: Malabarba, L.R., Reis, R.E., Vari, R.P., Lucena, Z.M.S., Lucena, C.A.S. (Eds.), Phylogeny and Classification of Neotropical Fishes. EDIPUCRS, Porto Alegre, pp. 13-48.

Lyra, M., Haddad, C.F.B., de Azeredo-Espin, A.M., 2016. Meeting the challenge of DNA barcoding Neotropical amphibians: polymerase chain reaction optimization and new COI primers. Mol. Ecol. Resour. http://dx.doi.org/10.1111/1755-0998.12648.

Meng, H., Li, X., Qiao, P., 2014. Population structure, historical biogeography and demographic history of the Alpine Toad Scutiger ningshanensis in the Tsinling Mountains of Central China. Plos One 9, e100729. http://dx.doi.org/10.1371/ journal.pone.0100729.

Morando, M., Medina, C.D., Avila, L.J., Perez, C.H.F., Buxton, A., Sites Jr., J.W., 2014 Molecular phylogeny of the New World gecko genus Homonota (Squamata: Phyllodactylidae). Zool. Scr. 43, 249-260. http://dx.doi.org/10.1111/zsc.12052.

Morrone, J.J., 2001. Biogeografía de América Latina y el Caribe. Manuales \& Tesis, Sociedad Entomológica Aragonesa, Zaragoza, España. 
Myers P., 1982. Origins and affinities of the mammal fauna of Paraguay. In: Mares, M.A., Genoways, H.H. (Eds.), Mammalian Biology in South America. Special PublicationSeries, Pymatuning Laboratory of Ecology, 6, pp.1-539.

Nei, M., 1987. Molecular Evolutionary Genetics. Columbia University Press, New York. Nicoli, L., 2014. Reappraisal of a ceratophryid frog from the Oligocene of Patagonia: assignation to Ceratophrys and new insight about its provenance. Ameghiniana 3 184-193. http://dx.doi.org/10.5710/AMGH.18.02.2014.1972.

Nicoli, L., 2015. New fossil species of the extant genus Lepidobatrachus (Anura, Ceratophryidae) from the late Miocene-early Pliocene of Central Argentina. J. Vertebr. Paleontol. http://dx.doi.org/10.1080/02724634.2015.981636. e981636.

Nicoli, L., Muzzopappa, P., Faivovich, J., 2016. The taxonomic placement of the Miocene Patagonian frog Wawelia gerholdi (Amphibia: Anura) Alcheringa an Australas. J. Palaeontol. 40, 153-160. http://dx.doi.org/10.1080/03115518.2016.1101998.

Nicoli, L., Tomassini, R.L., Montalvo, C.L., 2017. The oldest record of Ceratophrys (Anura, Ceratophryidae) from the Late Miocene of central Argentina. J. Vertebr. Paleontol. e1261360-5. http://dx.doi.org/10.1080/02724634.2017.1261360.

Nuñez, J.J., Wood, N.K., Rabanal, F.E., Fontanella, F.M., Sites, J.W., 2011. Amphibian phylogeography in the Antipodes: refugia and postglacial colonization explain mitochondrial haplotype distribution in the Patagonian frog Eupsophus calcaratus (Cycloramphidae). Mol. Phylogenet. Evol. 58, 343-352. http://dx.doi.org/10.1016/j. ympev.2010.11.026.

Olson, D.M., Dinerstein, E., Wikramanayake, E.D., Burgess, N.D., Powell, G.V.N., Underwood, E.C., D'Amico, J.A., Itoua, I., Strand, H.E., Morrison, J.C., Loucks, C.J., Allnutt, T.F., Ricketts, T.H., Kura, Y., Lamoreux, J.F., Wettengel, W.W., Hedao, P., Kassem, K.R., 2001. Terrestrial ecoregions of the world: a new map of life on Earth. Bioscience 51, 933-938. http://dx.doi.org/10.1641/0006-3568(2001) 051[0933:TEOTWA]2.0.CO;2.

Ortiz-Jaureguizar, E., Cladera, G.A., 2006. Paleoenvironmental evolution of southern South America during the Cenozoic. J. Arid Environ. 66, 498-532. http://dx.doi.org/ 10.1016/j.jaridenv.2006.01.007

Ottone, E.G., Reinarte Mazurier, S.M.E., Salinas, A., 2013. Palinomorfos Miocenos del subsuelo de Santiago del Estero, Argentina. Ameghiniana 50, 509-521. http://dx.doi. org/10.5710/AMEGH.24.07.2013.603.

Parham, J.F., Donoghue, P.C.J., Bell, C.J., Calway, T.D., Head, J.J., Holroyd, P.A., Inoue, J.G., Irmis, R.B., Joyce, W.G., Ksepka, D.T., Patané, J.S.L., Smith, N.D., Tarver, J.E., Van Tuinen, M., Yang, Z., Angielczyk, K.D., Greenwood, J.M., Hipsley, C.A., Jacobs, L., Makovicky, P.J., Muller, J., Smith, K.T., Theodor, J.M., Warnock, R.C.M., Benton, M.J., 2012. Best practices for justifying fossil calibrations. Syst. Biol. 61, 346-359. http://dx.doi.org/10.1093/sysbio/syr107.

Pascual, R., 1984. Late Tertiary mammals of southern South America as indicators of climatic deterioration. Quat. South Am. Antarct. Penins. 2, 1-30.

Pascual, R., Ortiz-Jaureguizar, E., Prado, J.L., 1996. Land mammals: paradigm for Cenozoic South American geobiotic evolution. In: Arratia, G. (Ed.). Contribution of Southern South America to Vertebrate Paleontology. Münchner Geowissenschaftliche Abhandlungen 30, 265-319, München, Germany.

Pennington, R.T., Prado, D.E., Pendry, C.A., 2000. Neotropical seasonally dry forests and Quaternary vegetation changes. J. Biogeogr. 27, 261-273. http://dx.doi.org/10. 1046/j.1365-2699.2000.00397.x.

Pinho, C., Rocha, S., Carvalho, B.M., Lopes, S., Mourão, S., Vallinoto, M., Brunes, T.O., Haddad, C.F.B., Gonçalves, H., Sequeira, F., Ferrand, N., 2009. New primers for the amplification and sequencing of nuclear loci in a taxonomically wide set of reptiles and amphibians. Conserv. Genet. Resour. 2, 181. http://dx.doi.org/10.1007/s12686009-9126-4.

Prado, D.E., 1993. What is the Gran Chaco vegetation in South America? I. A review. Contribution to the study of flora and vegetation of the Chaco. V. Candollea. 48, 145-172.

Prohaska, F.J., 1959. El polo de calor de América del Sur. IDIA 141, 27-30.

Pritchard, J., Stephens, M., Donnelly, P., 2000. Inference of population structure using multilocus genotype data. Genetics 155, 945-959.

Rabassa, J., Clapperton, C., 1990. Quaternary glaciations of the southern Andes. Quat. Sci. Rev. 9, 153-174. http://dx.doi.org/10.1016/0277-3791(90)90016-4.

Rambaut, A., Suchard, M.A., Xie, D., Drummond, A.J., 2013. Tracer v. 1.5. Available at: $<$ http://tree.bio.ed.ac.uk/software/tracer/>.

Ramos-Onsins, S.E., Rozas, J., 2002. Statistical properties of new neutrality tests against population growth. Mol. Biol. Evol. 19, 2092-2100. http://dx.doi.org/10.1093/ oxfordjournals.molbev.a004034.

Reed, D.H., Frankham, R., 2003. Correlation between fitness and genetic diversity. Conserv. Biol. 17, 230-237. http://dx.doi.org/10.1046/j.1523-1739.2003.01236.x.

Rizzini, C.T., 1979. Tratado de fitogeografia do Brasil. Editora da Universidade de São Paulo, São Paulo.

Roelants, K., Gower, D.J., Wilkinson, M., Loader, S.P., Biju, S.D., Guillaume, K., Moriau, L., Bossuyt, F., 2007. Global patterns of diversification in the history of modern amphibians. Proc. Natl. Acad. Sci. U.S.A. 104, 887-892. http://dx.doi.org/10.1073/ pnas.0608378104.

Rosenberg, N.A., 2004. DISTRUCT: a program for the graphical display of population structure. Mol. Ecol. Notes 4, 137-138. http://dx.doi.org/10.1046/j.1471-8286. 2003.00566.x.

Ruane, S., Pyron, R.A., Burbrink, F.T., 2011. Phylogenetic relationships of the Cretaceous frog Beelzebufo from Madagascar and the placement of fossil constraints based on temporal and phylogenetic evidence. J. Evol. Biol. 24, 274-285. http://dx.doi.org/ 10.1111/j.1420-9101.2010.02164.x.

Ruibal, R., 1962. Osmoregulation in amphibians from heterosaline habitats. Physiol. Zool. 35, 133-147.

Rull, V., 2008. Speciation timing and Neotropical biodiversity: the Tertiary-Quaternary debate in the light of molecular phylogenetic evidence. Mol. Ecol. 17, 2722-2729. http://dx.doi.org/10.1111/j.1365-294X.2008.03789.x.

Rull, V., 2011. Neotropical biodiversity: timing and potential drivers. Trends Ecol. Evol. 26, 508-513. http://dx.doi.org/10.1016/j.tree.2011.05.011.

Ruzzante, D.E., Walde, S.J., Gosse, J.C., Cussac, V.E., Habit, E., Zemlak, T.S., Adams, E.D.M., 2008. Climate control on ancestral population dynamics: insight from Patagonian fish phylogeography. Mol. Ecol. 17, 2234-2244. http://dx.doi.org/10. 1111/j.1365-294X.2008.03738.x.

Salfity, J.A., 1982. Evolución paleogeográfica del Grupo Salta (Cretácico-Eogénico), Argentina. Actas $5^{\circ}$ Congreso Latinoamericano de Geología, 1, 11-26. Buenos Aires.

Salzburger, W., Ewing, G.B., von Haeseler, A., 2011. The performance of phylogenetic algorithms in estimating haplotype genealogies with migration. Mol. Ecol. 20, 1952-1963. http://dx.doi.org/10.1111/j.1365-294X.2011.05066.x.

Schiesari, L., Gordo, M., Hodl, W., 2003. Treeholes as calling, breeding, and developmental sites for the Amazonian canopy frog, Phrynohyas resinifictrix (Hylidae). Copeia 2, 263-272. http://dx.doi.org/10.1643/0045-8511(2003) 003[0263:TACBAD]2.0. $\mathrm{CO} ; 2$.

Slatkin, M., Hudson, R.R., 1991. Pairwise comparisons of mitochondrial DNA sequences in stable and exponentially growing populations. Genetics 129, 555-562.

Solbrig, O., Cody, M.L., Fuentes, E.R., Glanz, W., Hunt, J.H., Moldenke, A.R., 1977. The origin of the Biota. In: Mooney, H.A. (Ed.), Convergent Evolution in Chile and California: Mediterranean Climate Ecosystems. Dowden, Hutchinson and Ross, Stroudsburg, pp. 13-26.

Souza, F.L., Uetanabaro, M., Landgref-Filho, P., Piatti, L., Prado, C.P.A., 2010. Herpetofauna, municipality of Porto Murtinho, Chaco region, state of Mato Grosso do Sul, Brazil. Check List 6, 470-475. http://dx.doi.org/10.15560/6.3.470.

Stamatis, C., Triantafyllidis, A., Moutou, K.A., Mamuris, Z., 2004. Mitochondrial DNA variation in Northeast Atlantic and Mediterranean populations of Norway lobster, Nephrops norvegicus. Mol. Ecol. 13, 1377-1390. http://dx.doi.org/10.1111/j.1365294X.2004.02165.x.

Stephens, M., Smith, N.J., Donnelly, P., 2001. A new statistical method for haplotype reconstruction from population data. Am. J. Hum. Genet. 68, 978-989. http://dx.doi. org/10.1086/319501.

Sugai, J.L.M.M., Faggioni, G.P., Piatti, L., Lemos, A.A., Souza, F.L., Prado, C.P.A., 2013. Lepidobatrachus asper Budgett, 1899 (Amphibia: Anura: Ceratophryidae): new country record, distribution map and natural history notes. Check List 9, 133-135. http://dx.doi.org/10.15560/9.1.133.

Tajima, F., 1989. Statistical method for testing the neutral mutation hypothesis by DNA polymorphism. Genetics 123, 585-595.

Tamura, K., Nei, M., 1993. Estimation of the number of nucleotide substitutions in the control region of mitochondrial DNA in humans and chimpanzees. Mol. Biol. Evol. 10, 512-526. http://dx.doi.org/10.1093/oxfordjournals.molbev.a040023.

Tamura, K., Stecher, G., Peterson, D., Filipski, A., Kumar, S., 2013. MEGA6: Molecular Evolutionary Genetics Analysis Version 6.0. Mol. Biol. Evol. 30, 2725-2729. http:// dx.doi.org/10.1093/molbev/mst197.

Tomassini, R.L., Agnolín, F.L., Oliva, C., 2011. First fossil record of the genus Lepidobatrachus Budgett, 1899 (Anura, Ceratophryidae), from the early Pliocene of Argentina. J. Vertebr. Paleontol. 31, 1005-1009. http://dx.doi.org/10.1080/ 02724634.2011 .596602

Tomassini, R.L., Montalvo, C.I., Deschamps, C.M., Manera, T., 2013. Biostratigraphy and biochronology of the Monte Hermoso Formation (early Pliocene) at its type locality, Buenos Aires Province, Argentina. J. South Am. Earth Sci. 48, 31-42. http://dx.doi org /10.1016/j.jsames.2013.08.002.

Tonni, E.P., 1974. Un nuevo cariámido (Aves, Gruiformes) del Plioceno Superior de la provincia de Buenos Aires. Ameghiniana 9, 366-372.

Vanzolini, P.E., 1963. Problemas faunísticos do Cerrado. In: Simpósio sobre o Cerrado. S. Paulo 13, 147.

Wells, K.D., 2007. The Ecology and Behavior of Amphibians. The University of Chicago Press, Chicago.

Werneck, F., 2011. The diversification of eastern South American open vegetation biomes: historical biogeography and perspectives. Quat. Sci. Rev. 30, 1630-1648. http://dx.doi.org/10.1016/j.quascirev.2011.03.009.

Willig, M.R., Presley, S.J., Owen, R.D., López-González, C., 2000. Composition and structure of bat assemblages in Paraguay: a subtropical-temperate interface. J. Mammal. 81, 386-401. http://dx.doi.org/10.1644/1545-1542(2000) $081<0386$ :CASOBA > 2.0.CO;2. 